\title{
Nutrient sensing via mTOR in T cells maintains a tolerogenic microenvironment
}

\section{Duncan Howie, Herman Waldmann and Stephen Cobbold*}

Sir William Dunn School of Pathology, University of Oxford, Oxford, UK

\section{Edited by:}

Claudio Mauro, Queen Mary

University of London, UK

\section{Reviewed by:}

Fulvio D'Acquisto, Queen Mary

University of London, UK

Claudio Procaccini, Consiglio

Nazionale delle Ricerche, Italy

Ruoning Wang, The Research Institute

at Nationwide Children's Hospital,

USA

\section{*Correspondence:}

Stephen Cobbold, Sir William Dunn

School of Pathology, University of

Oxford, South Parks Road, Oxford

OX1 3RE, UK

e-mail: stephen.cobbold@

path.ox.ac.uk
We have proposed that tolerance can be maintained through the induction, by Treg cells, of a tolerogenic microenvironment within tolerated tissues that inhibits effector cell activity but which supports the generation of furtherTreg cells by "infectious tolerance." Two important components of this tolerogenic microenvironment depend on metabolism and nutrient sensing. The first is due to the up-regulation of multiple enzymes that consume essential amino acids, which are sensed in naïve T cells primarily via inhibition of the mechanistic target of rapamycin (mTOR) pathway, which in turn encourages their further differentiation into FOXP3 ${ }^{+}$Treg cells. The second mechanism is the metabolism of extracellular ATP to adenosine by the ectoenzymes CD39 and CD73. These two enzymes are constitutively co-expressed on Treg cells, but can also be induced on a wide variety of cell types byTGF $\beta$ and the adenosine generated can be shown to be a potent inhibitor of $T$ cell proliferation. This review will focus on mechanisms of nutrient sensing in T cells, how these are integrated with TCR and cytokine signals via the mTOR pathway, and what impact this has on intracellular metabolism and subsequently the control of differentiation into different effector or regulatory $T$ cell subsets.

Keywords: mTOR, metabolism, immune regulation, $\mathrm{T}$ cell differentiation, tolerance

\section{INTRODUCTION}

The mechanistic target of rapamycin (mTOR) signaling acts as a principle integrator of nutrient-sensing pathways that control and coordinate the metabolism of the cell according to its need to proliferate or functionally differentiate $(1,2)$. When a naïve or resting $T$ cell recognizes its cognate antigen, the activation process involves synthesis of many new proteins, the induction of rapid cell proliferation, cytokine driven differentiation toward a range of effector functions, and chemokine induced cell movement to any site of inflammation. All these processes require a rapid increase in the main source of energy for the cell, which is ATP. While oxidative phosphorylation (OXPHOS) by the mitochondria is the most efficient means to generate large amounts of ATP, there seems to be a switch from primarily OXPHOS in resting $\mathrm{T}$ cells to an aerobic form of glycolysis, known as the "Warburg effect" (3), during activation and proliferation (4). This may be because glycolysis can use glucose as the basic source of carbon to generate many of the fundamental building blocks of the proliferating cell, such as amino acids, lipids, complex carbohydrates, and ribonucleotides (5). The mTOR pathway is strongly implicated in this metabolic switch because its activation up-regulates the surface expression of the glucose transporter, Glut1, probably as a result of TCR and CD28 signaling through phosphatidylinositide 3-kinase (PI3K) and protein kinase B (PKB also known as AKT) (6). AKT signaling via $\mathrm{mTOR}$ also leads to higher expression of amino acid and other nutrient transporters, such as the transferrin receptor (7). Signaling downstream of mTOR via ribosomal S6 kinase and $4 \mathrm{E}-\mathrm{BP} 1$ is also required to initiate protein synthesis from mRNA at the ribosome (8). Rapamycin is a drug (trade name sirolimus) that inhibits mTOR by forming a complex with FKBP12, which binds to raptor and disrupts the activity of the mTORC1 complex. Rapamycin is used clinically as an immunosuppressive agent, particularly in allogeneic transplantation, and has over recent years gained interest as a potential alternative to calcineurin inhibitors, which not only have renal toxicity but are also thought to block the induction of regulatory $\mathrm{T}$ cells (9).

\section{MECHANISMS OF PERIPHERAL TOLERANCE REGULATORY T CELLS ARE ENRICHED WITHIN TOLERATED TISSUES}

It has recently become clear that tolerance is associated with Treg cells that act within a highly localized microenvironment to maintain a state of acquired immune privilege $(10,11)$. Tolerance to skin grafts can be induced using a short course of non-depleting CD4 antibodies in mice expressing a TRC transgenic, monoclonal population of $\mathrm{CD}^{+} \mathrm{T}$ cells such that every $\mathrm{T}$ cell recognizes the male antigen presented by MHC-II on the graft (12). This tolerance is not due to clonal deletion as the graft recipients contain normal numbers of male specific $\mathrm{T}$ cells, including a proportion that show evidence of recent activation, by expression of CD44 and IL-2. As these mice are on a $\mathrm{RAG}^{-1-}$ background, there are no FOXP3 ${ }^{+}$Treg cells present in the naïve animal pre-grafting, but after tolerance induction, peripherally induced, $\mathrm{FOXP}^{+}{ }^{+}$Treg cells are found gradually increasing over time (up to $50 \%$ ) within the tolerated graft tissue, but only in small numbers $(1-2 \%)$ in the lymph nodes or spleen (12). This suggests that the Treg cells are acting to control the response of effector $\mathrm{T}$ cells primarily within the graft itself.

This can be demonstrated where alloantigen specific tolerance has been induced to a skin graft (e.g., by a short period of coreceptor blockade with non-depleting anti-CD4 and CD8 
monoclonal antibodies), and then that tolerated graft has been removed and re-transplanted onto a secondary recipient with no immune system of its own (e.g., a recombinase activating gene 1 knock out mouse). This skin graft is accepted by the secondary recipient as it has no $\mathrm{T}$ cells to cause any rejection. If, however, we treat the recipient at the time of graft transfer with monoclonal antibodies that inactivate or deplete FOXP3 ${ }^{+}$Treg cells (e.g., antiCD25, or if the original recipient carries the hCD2.FOXP3 knock in reporter, anti-hCD2), the transferred skin grafts are rapidly rejected $(11,13)$. This shows that the re-transplanted, originally tolerated skin graft carried over within it perfectly functional effector T cells, but that it also contained FOXP ${ }^{+}$Treg cells that were actively blocking the ability to cause rejection. By studying the changes in gene expression between tolerated and rejecting skin grafts, and comparing dendritic cells (DCs) when they interact with Treg cells in the presence or absence of antigen (14-16), it was found that while co-stimulatory ligands and antigen presentation by DCs were down-regulated, there was also an up-regulation of a number of enzymes that either catabolize or utilize essential amino acids (EAAs) (17). In the context of a restricted microenvironment within tissues, where there may not be free exchange of amino acids and other nutrients with plasma in the vasculature, the local depletion of EAAs by these enzymes could be an effective mechanism to control the immune response via the mTOR nutrient-sensing pathway (Figure 1). Conversely, edema and breakdown of the vasculature may provide an excess of amino acids that would promote $\mathrm{T}$ cell activation and graft rejection. This regulation by amino acid availability might be particularly effective if regulatory $\mathrm{T}$ cells were more resistant to the effects of amino acid starvation. It has been shown that the intracellular concentration of leucine, a particularly strong activator of mTOR, is controlled by a TCR induced expression of the neutral amino acid transporter slc7a5 in Th1 and Th2 effector T cells, where it is required for their activation and differentiation, but regulatory $\mathrm{T}$ cells seem not to depend on this particular transporter (18).

\section{IDO MEDIATED TRYPTOPHAN CATABOLISM AS A MECHANISM OF IMMUNE REGULATION}

The maternal immune response to paternal alloantigens expressed on the developing fetus is in many ways similar to that seen in transplantation. The expression of the enzyme indoleamine 2,3 dioxygenase (IDO) in the placenta during pregnancy was shown to be important for avoiding that immune response by the finding that a specific inhibitor, 1-methyl tryptophan, could induce spontaneous abortion of semi-allogeneic, but not syngeneic, conception (19). In vitro experiments showed that IDO seemed to act primarily through depletion of tryptophan, although there is some evidence that the kynurenine products of tryptophan catabolism may also play a role (20). The tryptophan depletion is sensed, at least in part, by general control non-repressed 2 (GCN2), which is one of the initiators of the integrated stress response, activation of which leads to a block in the proliferation of CD8 effector T cells (21). GCN2 is also required for the survival of T cells, including $\mathrm{CD}^{+}{ }^{+}$Treg cells, during periods of amino acid starvation (17), but it was not essential for $\mathrm{T}$ cells to sense the absence of other EAAs and halt their proliferation in vitro (17). The in vitro induction of forkhead box P3 (FOXP3) as a result of

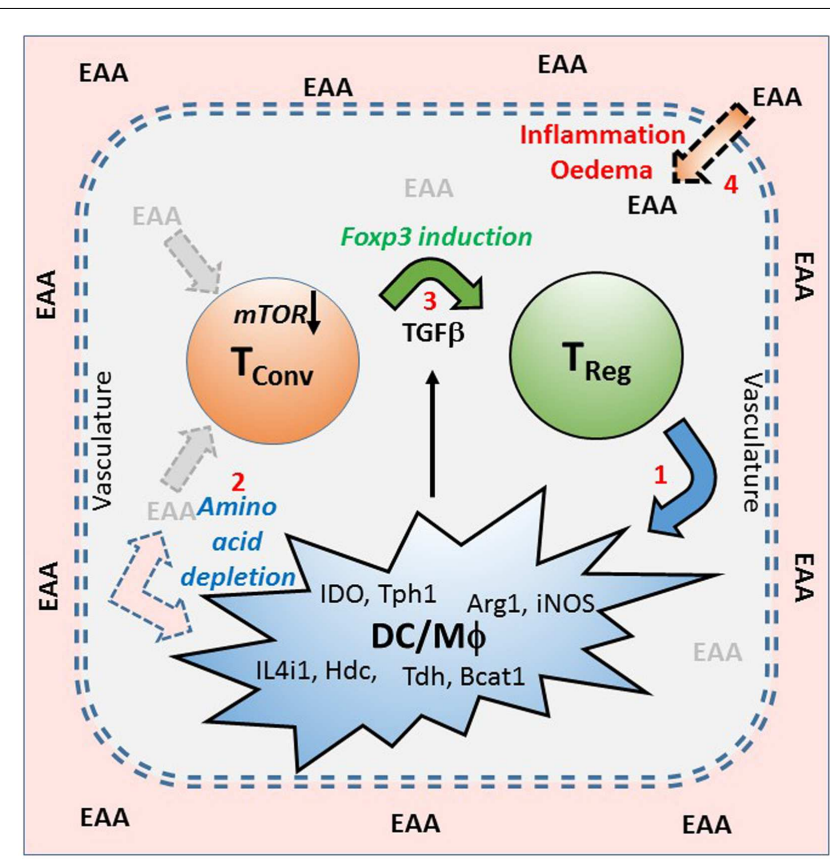

FIGURE 1 | A model of infectious tolerance that depends on a nutrient depleted microenvironment maintained by Treg cells within tissues. This model proposes that immunological tolerance is maintained within tissues by the localized depletion of nutrients, particularly the essential amino acids (EAA), which are required for the proliferation and effector function of conventional T cells (Tconv). Amino acid depletion is primarily as a result of regulatory T cells (Treg) inducing (1), in dendritic cells (DC) and macrophages (M申), a range of enzymes that catabolize (2) or utilize EAA (examples are shown). This lack of EAA is sensed via the mTOR pathway which, in the presence of TGF $\beta$, encourages the expression of FOXP3, and the induction of further Treg (3). Under conditions of tolerance the intact vasculature maintains a barrier between the blood and the tissues, but if there is inflammation or damage to the vasculature, causing edema, then EAA can leak into the tissues (4) and contribute to a breaking of the tolerant microenvironment.

stimulating naïve $\mathrm{CD} 4^{+} \mathrm{T}$ cells in the presence of low doses of TGF $\beta$ was also unaffected by activating the GCN2 pathway with histidinol (an inhibitor of histidyl-tRNA synthetase) while in contrast, inhibition of the mTOR pathway with rapamycin gave a synergistic increase in FOXP3 expression (17). It has recently been found that tryptophan levels can be sensed via mTOR and PKC $\theta$ signaling (22).

\section{DEPLETION OF ESSENTIAL AMINO ACIDS MAINTAIN AN IMMUNE PRIVILEGED MICROENVIRONMENT WITHIN TOLERATED TISSUES}

Indoleamine 2,3 dioxygenase may have been the first example of immune regulation due to amino acid catabolism because tryptophan is thought to be present at the lowest concentration of all the EAAs, at least in the plasma. Recently, it has been shown that mast cells that seem to be specifically associated with tolerated skin grafts, express the enzyme tryptophan hydroxylase (TPH1) (23), which utilizes tryptophan to synthesize serotonin. TPH1 knockout mice, unlike wild type controls, could not be made tolerant of allogeneic heart grafts using costimulation blockade, but this could be reconstituted with wild type mast cells. Providing 
5-hydroxytryptophan to bypass the defect in serotonin synthesis in TPH1 knockout mice was not sufficient to allow the induction of tolerance, suggesting that the mechanism was dependent on tryptophan depletion rather than serotonin synthesis (24). Similarly, arginase (ARG1) expression has been implicated in regulating the immune response during pregnancy $(25,26)$ and has also been associated with a presumed protective, type 2 , population of macrophages within tissues (27). Arginine is the substrate for the inducible form of nitric oxide synthase (iNOS), which is normally associated with classically activated macrophages and a Th1 effector cell response, but under limiting concentrations of arginine in vitro, both arginase and iNOS can cause sufficient depletion of arginine to cause mTOR inhibition and subsequently block T cell proliferation (17). Another enzyme called IL4-induced 1 (IL4i1) for its induction in myeloid cells under Th2 conditions, depletes EAAs with hydrophobic side chains such as phenylalanine (28). IL4i1 was also found to be induced in DC when co-cultured with Treg cells (17).

Expression of many of these EAA consuming enzymes could be induced within skin grafts in vivo (17) and in DCs in vitro (17) by a cognate interaction with antigen specific Treg cells, either by specific cytokines such as TGF $\beta$, IL4, or interferon- $\gamma$ (IFN- $\gamma$ ) or via cell surface interactions such as CTLA4 (17). In addition, catabolic enzymes specific for threonine (threonine dehydrogenase - TDH) and the branched chain amino acids (branched chain amino acid aminotransferase - Bcat1) were more closely associated with the inflammation and wound healing even when skin was grafted onto recipients with no adaptive immune system (17). This suggests that tissues such as skin have a built in nutrient-sensing mechanism for protecting themselves against immune attack that might be important for maintaining self-tolerance, which might explain why long-term surviving, fully healed in syngeneic skin grafts also had higher levels of these particular enzymes, as well as an increased infiltration by FOXP3 ${ }^{+}$Treg cells (16).

All these observations led us to propose that tolerance may be maintained by regulatory $\mathrm{T}$ cells that induce a tolerogenic microenvironment within tissues that is, at least in part, dependent on the induction of many different enzymes that deplete the local pool of EAAs. This lack of EAAs is sensed by T cells via the mTOR pathway, which inhibits the generation and function of effector $\mathrm{T}$ cells, while encouraging the development of further FOXP3 ${ }^{+}$Treg cells (Figure 1). This mechanism may explain the phenomenon known as "infectious tolerance" where it was shown that naïve $\mathrm{T}$ cells that co-existed with regulatory $\mathrm{T}$ cells in a tolerant environment acquired all the properties of the original tolerant $\mathrm{T}$ cells within 3 weeks, such that tolerance was maintained if the original cohort of tolerant $T$ cells were subsequently depleted (29). The question then arises as to how the consequent inhibition of mTOR regulates the activation and differentiation of different functional $\mathrm{T}$ cell subsets.

\section{mTOR INTEGRATES NUTRIENT SENSING AND ACTIVATION SIGNALS IN T CELLS \\ THE mTOR PATHWAY IN T CELLS}

The mTOR pathway (Figure 2) acts generally to coordinate many aspects of cell growth and metabolism, including the response to hypoxia and the biogenesis and oxidative capacity of mitochondria

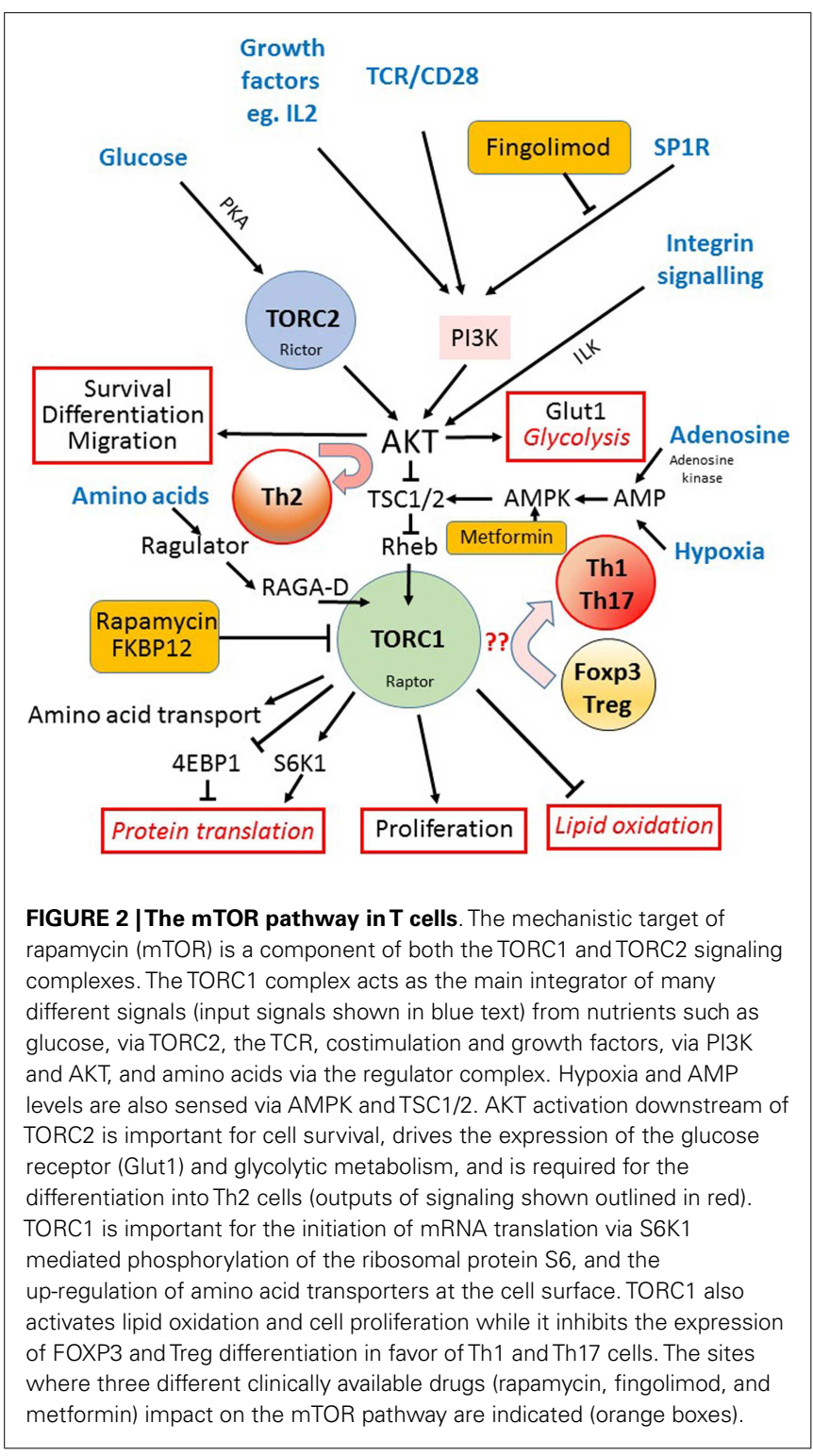

(30). mTOR forms two distinct complexes that seem to have different signaling functions (TORC1 and TORC2) (31). TORC1 is thought to be the main nutrient-sensing complex and is composed of the serine/threonine kinase mTOR itself, the scaffolding protein raptor, the positive accessory proteins FKB12, deptor, and mLST8, and a regulatory subunit PRAS40 that is a target of AKT downstream of PI3K signaling (32). Most signals, which eventually lead to activation of the TORC1 complex, including glucose, cytokines, growth factors, and costimulation in T cells, do so via PI3K signaling, which eventually phosphorylates mTORC1 via the tuberous sclerosis (TSC) $1 / 2$ complex and the ras homolog expressed in brain (Rheb). Rheb is localized within the cell in a Rab7 ${ }^{+}$lysosomal compartment and the interaction between TORC1 and Rheb is entirely dependent on the sensing of sufficient amino acids. Although the molecular sensor of amino acids in mammals remains unclear, downstream signaling requires the four ras-related GTP binding (or RAG GTPase - RRAG) proteins 
(A-D) together with the ragulator complex $(33,34)$, so that a lack of available amino acids acts as a potent inhibitor of TORC1 activity. The immunosuppressive drug rapamycin binds to FKB12 and disrupts the formation and function of the TORC1 complex (35) and therefore has a similar effect on cells as does amino acid starvation. Conversely, TORC1 activation drives protein synthesis via phosphorylation of S6K1, which phosphorylates the ribosomal protein $\mathrm{S} 6$ and initiates the translation of messenger RNA. At the same time, 4E-BP1, an inhibitor of protein translation, is also deactivated by mTOR-mediated phosphorylation.

Much less is known about how the TORC2 complex is regulated: there is some evidence that it senses reactive oxygen species and is involved in sphingolipid homeostasis at the plasma membrane (36), while it also seems to sense glucose availability via a cAMP/PKA pathway (37). TORC2 is thought to be negatively regulated by TORC1 activity via Sin 1 phosphorylation (38). Rapamycin therefore indirectly activates TORC2 in the short term, but chronic long-term inhibition (over hours to days) of TORC1 (39) or by amino acid starvation (40) seems to eventually reduce the activity of TORC2. TORC2 controls various spatial aspects of cell growth, in particular cell polarity and responses to chemotactic signals via $\mathrm{G}$ protein coupled activation of RAS (41).

\section{mTOR SIGNALING INHIBITS FOXP3 EXPRESSION}

It has long been known that mTOR inhibition by rapamycin is potently immunosuppressive, partly because it blocks the ability of $\mathrm{T}$ cells to respond to interleukin 2 (IL-2) signaling via PI3K and consequently their ability to proliferate in response to antigen (42). More recently, it is has become clear that mTOR signaling also controls the differentiation of CD4 ${ }^{+}$T helper cell subsets (43), and in particular, the expression of the "master" transcription factor for regulatory T cells, FOXP3. mTOR activation downstream of the TCR, CD28 costimulation and cytokine mediated PI3K signaling is generally required for the proliferation and differentiation of effector T cells but this is inhibitory for FOXP3 expression (44, 45). Signaling downstream of the sphingomyelin phosphate receptor (S1PR), which is required for lymphocyte trafficking and exit from the lymph nodes, can also activate mTOR (46). Interestingly, this pathway is the target of the immunosuppressive drug known as Fingolimod/FTY720 (47), which also has the potential to promote Treg cell development (48). Although the exact mechanism by which mTOR inhibition enhances FOXP3 expression has not been clarified, there is some evidence that implicates a number of different pathways. These could act via poorly defined effects on FOXP3 translation via inhibition of S6K1 and reduced phosphorylation of the ribosomal protein S6. Additionally, mTOR could act either indirectly via suppressor of cytokine signaling 3 (SOCS3) $(49,50)$ or directly on signal transducer and activator of transcription 3 (STAT3) downstream of IL-6 and the satiety hormone leptin (51). Phospho-STAT3 may then compete for the IL-2 driven STAT5 enhancement of FOXP3 transcription (52). In addition, FOXO3a $(53,54)$ and the TGF $\beta$ signaling component SMAD3, two transcription factors promoting FOXP3 expression, are negatively regulated by AKT downstream of TORC2 (55). Evidence from mice with $\mathrm{T}$ cell targeted deficiencies in either raptor (TORC1) or rictor (TORC2) suggests that TORC1 tends to promote Th1 differentiation (43) while TORC2 may bias toward Th2 via $\mathrm{AKT}$ and $\mathrm{PKC} \theta$ (56). Inhibition of both complexes seems to be required for the optimal induction of FOXP3 ${ }^{+}$Treg cells while Th17 cell development seems to be independent of TORC2, but is inhibited by rapamycin in favor of FOXP3 ${ }^{+}$Treg cells (57).

\section{WHILE mTOR INHIBITION IS REQUIRED FOR FOXP3 EXPRESSION, mTOR ACTIVATION IS NEEDED FOR REGULATORY FUNCTION}

Mechanistic target of rapamycin inhibition therefore seems to be associated with tolerance and FOXP3 ${ }^{+}$Treg cell induction, and this appeared to be confirmed by T cell specific mTOR knockout mice, which develop an excess of FOXP $3^{+}$Treg cells over Th1 and Th2 effector cells (43). Recent data, however, from FOXP3Cre.Raptor ${ }^{\mathrm{fl} / \mathrm{fl}}$ mice where TORC1 activity has been specifically knocked out in FOXP3 ${ }^{+}$Treg cells, indicates that TORC1 activation is still required for Treg cells to function, as evidenced by the development of an autoinflammatory condition very similar to scurfy or FOXP3 deficient mice (58). CD4-Cre.Raptor ${ }^{\mathrm{f} / \mathrm{fl}}$ mice, lacking TORC1 activity in all $\mathrm{T}$ cells, however, did not develop disease, presumably because this also compromised the effector T cells. This raises the possibility that the optimal induction and expansion of $\mathrm{FOXP}^{+}$Treg cells takes place in the nutrient depleted microenvironments associated with tolerance, but the Treg cells only become fully active and proliferative when there is inflammation that needs to be controlled, which requires a re-activation of their mTOR pathway. Interestingly, it had previously been postulated that the optimal functional induction of FOXP3 ${ }^{+}$Treg cells required alternate cycles or oscillations of mTOR inhibition, first to promote induction, and subsequently mTOR activation to promote proliferation (59).

\section{MODULATION OF FOXP3 EXPRESSION BY ADENOSINE AND HYPOXIA}

Hypoxia induced factor (HIF) $1 \alpha$, another downstream target of TORC1, has also been implicated either as a positive $(60,61)$ or a negative $(62,63)$ regulator of FOXP3 expression. HIF1 $\alpha$ is a BHLH-Pas transcription factor that has an essential role in the response of cells to hypoxia and which is able to bind directly to FOXP3 protein to target it for proteosomal degradation (62). The level of HIF1 $\alpha$ transcription is controlled by NFK $\beta$ (64), but its activity is mainly controlled post-translation by an oxygen mediated ubiquitination and degradation controlled by the von Hippel-Lindau tumor suppressor complex with additional positive regulation via a TORC1 mediated phosphorylation (65). Activation of naïve T cells under hypoxic conditions has also been suggested to enhance FOXP3 expression and the differentiation to Treg cells (60), but it is not clear whether this is a direct effect of HIF1 $\alpha$ on FOXP3 expression, or whether it is an indirect effect of HIF $1 \alpha$ feedback inhibition of mTOR (66). Hypoxia is associated with raised levels of AMP within the cell, and the enzyme AMP activated protein kinase (AMPK) causes inhibition of mTOR via TSC1/2 (67, 68).

AMP and adenosine are particularly relevant to immune regulation, as TGF $\beta$ is able to induce in a range of hematopoietic cells the co-expression of two ectoenzymes, CD39 and CD73 (69) that are also constitutively expressed on Treg cells (70). These two enzymes (Figure 3) act at the cell surface to convert extracellular sources of ATP, which is associated with inflammation and cell necrosis, into the anti-inflammatory product adenosine. 


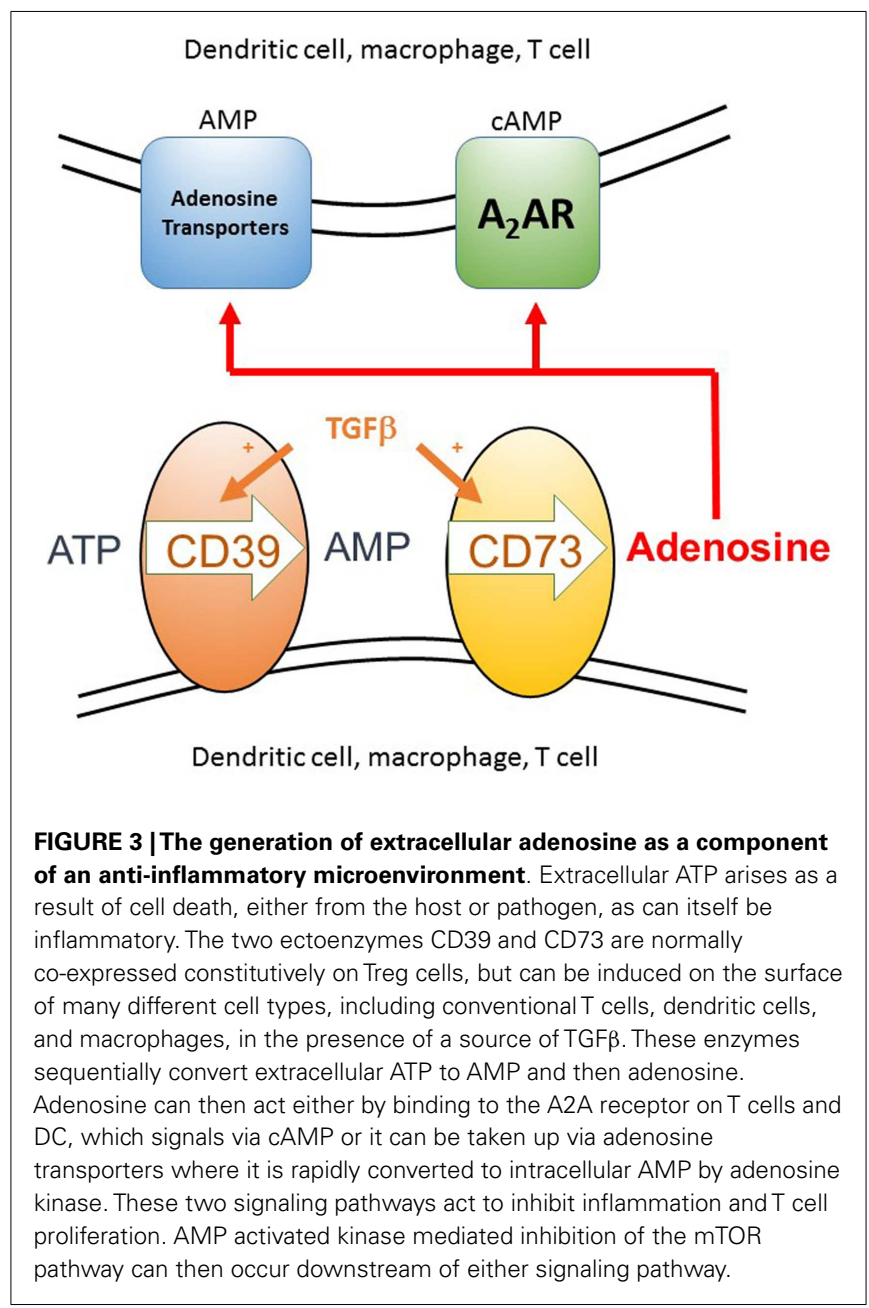

Extracellular adenosine can generate the second messenger cAMP within the target cell via activation of specific $\mathrm{G}$ protein coupled receptors on the cell surface [e.g., $A_{2 A} R$ on $T$ cells $\left.(71,72)\right]$ or it can be directly taken up by specific adenosine transporters (73) where, once inside the cell, it is rapidly converted to AMP by adenosine kinase. AMP is also generated in the cell downstream of $G$ protein signaling via cAMP, which is subsequently broken down to AMP by phosphodiesterases. Although there is evidence that this pathway is relevant to tumors escaping immune surveillance $(74,75)$, it remains, however, to be resolved whether adenosine is as an important component of the anti-inflammatory microenvironment within tolerated tissues.

\section{T CELLS DISPLAY METABOLIC AND FUNCTIONAL PLASTICITY IN RESPONSE TO DIVERSE ENVIRONMENTAL CUES}

T cells not only adapt to their environment by changing metabolic mode, but in addition their chosen fuel source and metabolites, to a large extent, affect their fate and function (Figure 4). T cells use glucose and glutamine as their primary source of energy but can switch to ketone bodies and fatty acid use under certain circumstances (76). Glucose is the primary substrate for ATP production in T cells $(77,78)$. During glycolysis, glucose is converted to two molecules of pyruvate and two molecules of ATP in an

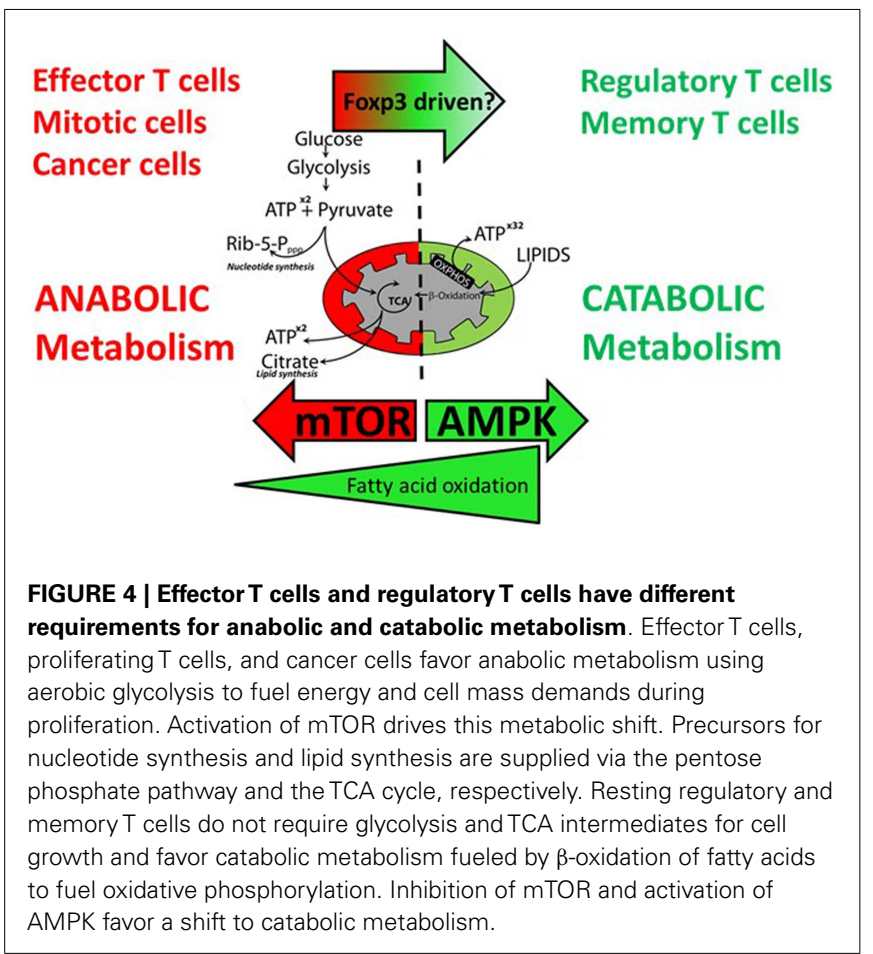

oxygen-independent process. Pyruvate generated from glycolysis is oxidized in the TCA cycle yielding $\mathrm{NADH}$ and FADH2, which is used to fuel OXPHOS. OXPHOS is oxygen dependent and efficiently yields as much as 36 molecules of ATP per molecule of glucose. In order to mount an effective immune response $\mathrm{T}$ cells must expand rapidly and can achieve doubling times as low as 2-6 h (79). To fuel this expansion T cells undergo a major metabolic shift from primarily catabolic fatty acid oxidation (FAO) driven OXPHOS to anabolic glycolysis and glutaminolysis during activation, then revert back to FAO in the memory phase. Glycolysis is an amphibolic process that although less efficient in net ATP production, fuels rapid $\mathrm{T}$ cell growth by providing NADPH and ribose from the pentose phosphate pathway for reductive biosynthetic reactions and nucleotide synthesis and fuels lipid synthesis via citrate from the TCA cycle. During this process, glucose is incompletely oxidized and is fermented to lactate while glutamine is converted to glutamate, aspartate, and ammonia. This shift to oxygen-independent glycolysis in the context of normoxia has been termed aerobic glycolysis and is a feature of cancer cells, where the process is termed Warburg metabolism, reviewed in Ref. (80).

Multiple environmental nutritional signals are integrated by $\mathrm{T}$ cells via mTOR and AMPK to control their choice of metabolism and function. These signals include glucose and glutamine concentration, oxygen tension, amino acid concentration, lipids, salt concentration $(\mathrm{NaCl})$, leptin concentration, and ATP:ADP ratio. In addition, immune-specific inputs such as $\mathrm{T}$ cell receptor triggering and co-stimulatory/inhibitory signals and cytokines are integrated by $\mathrm{T}$ cells to change their metabolic mode.

\section{GLUCOSE IS REQUIRED FOR T CELL ACTIVATION}

Glucose is critical for $\mathrm{T}$ cell activation. It is the primary carbon source for macromolecules such as lipids and nucleotides in T cells 
and can fuel the pentose phosphate pathway to generate NADPH reducing equivalents. During activation the $\mathrm{T}$ cell increases its rate of glucose metabolism and up-regulates cell surface Glut1 receptors to transfer glucose from the extracellular space $(81,82)$. Concomitant with the increase in surface Glut1, hexokinase is also upregulated $(83,84)$ after T cell activation. Hexokinase phosphorylates glucose thus trapping it in the cytoplasm and maintaining a glucose gradient across the plasma membrane to maintain facilitated diffusion of glucose. Indeed, even in the presence of glutamine, in the absence of glucose $\mathrm{T}$ cell survival and proliferation is severely impaired (77). Effector T cells (Teff) specifically Th17, Th1, and Th2 are particularly glycolytic and dependent on glucose and accumulate preferentially in Glut1 transgenic mice at the expense of Treg cells. Treg cells preferentially use fatty acids as a fuel, their development is enhanced in the presence of excess fatty acids (78).

\section{GLUTAMINE AS AN IMPORTANT CARBON SOURCE FOR T CELLS}

Glutamine is the most abundant amino acid in serum (85) and has also been implicated in immune regulation (86). It is essential for $\mathrm{T}$ cell activation as a source of nitrogen and as a key anapleurotic substrate enabling nucleotide synthesis and redox control in addition to fueling metabolism via the TCA cycle following conversion to $\alpha$-ketoglutarate. $\mathrm{T}$ cells consume glutamine at an equivalent rate to glucose $(87,88)$. Activation of T cells triggers a rapid 5- to 10-fold increase in SNAT1 and SNAT2 (89) (sodium dependent neutral amino acid transporter) glutamine transporter expression and glutamine import via a CD28 and ERK/mitogenactivated protein kinase (MAPK) dependent mechanism. Naïve T cells transport glutamine into the cell via ASCT2 (slc1a5) (90) where the concentration of glutamine becomes sufficient to act as an efflux substrate to drive the system $L$ neutral amino acid transporter slc7a5 in complex with CD98 (slc3a2) to import neutral amino acids into the cell. Sustained neutral amino acids and glutamine are essential for TCR/CD28 driven mTORC1 activation, but not other TCR signaling pathways such as MAPK or IKK (90). Activated TORC1 subsequently prolongs glutamine anapleurosis by activating glutamate dehydrogenase via indirectly inhibiting transcription of its inhibitor, SIRT4 (91). Glutamine can fuel the TCA cycle for anabolic and catabolic metabolism in the presence or absence of glucose and in the presence of hypoxia (92). Cells require acetyl coenzyme A for lipid synthesis. During hypoxia or active proliferation where aerobic glycolysis is engaged glucose carbons are converted to lactate and diverted away from the TCA cycle. Under these conditions cells can use reductive metabolism of $\alpha$-ketoglutarate as an alternative anaplerotic route to produce acetyl co-A for the synthesis of lipids (93).

\section{FATTY ACID METABOLISM}

Resting naïve $\mathrm{T}$ cells, memory $\mathrm{CD} 8 \mathrm{~T}$ cells and resting regulatory $\mathrm{T}$ cells share FAO as a common default metabolic mode (78, 94-96). This metabolic state enhances ATP production through mitochondrial OXPHOS while minimizing anabolic processes required for increased cell mass during proliferation. Environmental lipid concentration has a role in determining the fate of differentiating $\mathrm{T}$ cells. Treg cell homeostasis requires environmental lipids, which activate the nuclear receptors peroxisome proliferator activated receptor (PPAR) $\alpha$ and PPAR $\gamma$ that function as fatty acid sensors and regulators of lipid metabolism. These receptors promote FOXP3 expression by CD4 T cells in response to TGF $\beta$ (97). Clinically, PPAR $\gamma$ agonists downregulate the production of proinflammatory cytokines such as IL-6, TNF $\alpha$, and leptin (98). Provision of fatty acids to $\mathrm{T}$ cells in vitro promotes differentiation to Treg cells while inhibiting effector differentiation (78). These observations may explain the severe acute immunosuppression associated with calorific starvation observed in humans.

\section{DIETARY NaCL AND INFLAMMATION}

Recent evidence suggests that dietary sodium chloride concentration may play a role in controlling inflammation by inhibiting induction of peripheral Treg cells and favoring the induction of Th17 and Th2 cells $(99,100)$. Elevated levels of $\mathrm{NaCl}$ by just $40 \mathrm{mM}$ have been shown to activate p38 MAPK signaling, resulting in activation of the osmosensitive form of NFAT5 (also known as TONEBP) leading to activation of serum glucocorticoid kinase 1 (SGK1), an AGC serine/threonine kinase (99). SGK1 has been shown to govern salt transport and salt homeostasis in multiple cell types dependent on TORC2 activity (101). Raised levels of salt were shown to turn on SGK1 expression, enhance IL-23R expression, and augment TH17 cell differentiation $(99,100)$. Powell and colleagues showed that after activation by mTORC2, SGK1 promoted $\mathrm{T}$ helper type $2\left(\mathrm{~T}_{\mathrm{H}} 2\right)$ differentiation by negatively regulating degradation of the transcription factor JunB mediated by the E3 ligase Nedd4-2 (102). The same group also showed that SGK1 turns off IFN- $\gamma$ via TCF-1. Sodium chloride concentrations vary anatomically, the concentration in plasma is approximately $140 \mathrm{mM}$, whereas in insterstitium and lymph nodes it is much higher ranging from 160 to $250 \mathrm{mM}(103,104)$. Thus, it is possible that sodium concentration limits pro-inflammatory activation of T cells in the blood while allowing Th17 differentiation in tissues and lymph nodes.

\section{LEPTIN AS A PRO-INFLAMMATORY CYTOKINE}

Leptin is an IL-6-like cytokine produced by adipocytes (termed an "adipokine"), which acts directly on the hypothalamus as a satiety hormone and also has effects on metabolism and $\mathrm{T}$ cell functions $(105,106)$. Adipokines are hormones or cytokines secreted by adipocytes, which have pleiotropic effects on the nutritional status and immune system of the organism. These include the cytokines IL-1, IL-6, IFN- $\gamma$, TNF $\alpha$ as well as leptin and adiponectin. Leptin is produced at high levels constitutively by regulatory $\mathrm{T}$ cells, which also express the leptin receptor (ObR) (107). Leptin is required for activated $\mathrm{T}$ cell proliferation and cytokine production in part via inducing up-regulation of mRNA and surface expression of the Glut1 receptor and glucose uptake (108). Leptin in combination with $\mathrm{T}$ cell receptor triggering induces activation of $\mathrm{CD} 4{ }^{+} \mathrm{CD} 45 \mathrm{RA}$ naïve $\mathrm{T}$ cells but inhibits activation of $\mathrm{CD}^{+}{ }^{+} \mathrm{CD} 45 \mathrm{RO}^{+}$memory $\mathrm{T}$ cells in humans (109). It skews these cells to produce pro-inflammatory cytokines including IFN- $\gamma$ and $\mathrm{TNF} \alpha$ and leptin itself. Leptin functions to negatively regulate Treg cell activity and proliferation. Leptin deficient mice $(o b / o b)$ and leptin receptor deficient mice $(d b / d b)$ have decreased susceptibility to autoimmunity and increased numbers of Treg cells (107, 110, 111). Neutralization of leptin in Treg cell cultures enhances 
their IL-2 dependent proliferation while maintaining suppressive function. Thus, leptin appears to function as a feedback control mechanism to control Treg cell activity in response to nutrient availability.

\section{SIGNALING MECHANISIMS REGULATING T CELL METABOLISM}

mTOR COORDINATES METABOLISM AND T CELL DIFFERENTIATION

The activation of naïve $T$ cells has been primarily associated with glucose metabolism, even under aerobic conditions, as this not only provides a source of ATP for energy and effector cell activity but also generates the precursors for nucleotide synthesis and lipogenesis that are required for cell proliferation (5). Under conditions of nutrient restriction and mTOR inhibition, however, it would be expected that $\mathrm{T}$ cells would switch to more efficient pathways of energy generation, such as OXPHOS and FAO, both of which require active mitochondria. Indeed, it has been shown that Treg cells have higher levels of AMPK activity, which as we have seen leads to mTOR inhibition, and this in turn reduces the expression of the glucose transporter (Glut1) and enhances lipid oxidation, effects, which can be reversed in Glut1 over-expressing transgenic mice (78). Multiple intracellular signaling pathways control the choice of metabolic activity engaged by $\mathrm{T}$ cells.

\section{c-Myc}

The proto-oncogene c-Myc is a critical positive regulator of both gylcolysis and glutaminolysis and as such has a potentially important role in $\mathrm{T}$ cell plasticity. c-Myc and its binding partner max binds to over 10,000 sites in mammalian genomes at a consensus E-box sequence CAGCTG $(112,113)$. c-Myc has a fundamental role in controlling metabolism. It increases transcription of all the glycolysis genes (114) and also the glutamine transporters ASCT2 and SN2 by binding to their promoters (114-116). cMyc increases usage of pentose phosphate pathway, glycolysis, and glutaminolysis (84) and also augments mitochondrial biogenesis via up-regulation of PGC1 (117-119) and the transferrin receptor TFRC (120), which is necessary to provide iron for the heme containing proteins of the electron transport chain. Thus, c-Myc drives cells toward anabolic metabolism, at the same time it promotes cell division via glutaminolysis providing the anaplerotic substrate aKG needed for synthesis of polyamines required for T cell proliferation (115). Myc deletion in T cells using inducible tamoxifen cre-lox systems leads to inhibition of glycolysis and glutaminolysis (84). Glutamine deprivation inhibits $\mathrm{T}$ cell activation induced growth and proliferation (84).

\section{ESTROGEN RECEPTOR RELATED RECEPTOR $\alpha$}

Estrogen receptor related receptor $\alpha(\operatorname{ERR} \alpha)$ is an orphan receptor, one of three members of a family $\alpha, \beta$, and $\gamma$, which bind to a DNA consensus site termed the ERR response element (TNAAGGTCA) in multiple genes (121). Despite its name it is not activated by estrogen or related hormones, but seems to be constitutively active, having an active ligand binding region in the absence of ligand (122). ERR $\alpha$ is important in immune reprograming as it seems to function to "rewire" cells to use glucose for anabolism (123). The glucose transporter glut1 and glucose uptake are inhibited in ERR $\alpha$ null T cells, and by chemical inhibition of ERR (123).
$\mathrm{ERR} \alpha$ physically interacts with PGC1 $\alpha$ and PGC1 $\beta$ (124), which act as co-activators to activate transcription of a number of genes important for FAO (MCAD, CPT1B), TCA cycle (IDH3A, AC02), and OXPHOS (CYCS, ATP5B) in multiple cell types (125). Interaction of ERR $\alpha$ with the transcriptional co-repressor RIP140 results in down regulation of many of the genes, which PGC1 $\alpha / \beta$ activates (126-128). Acute inhibition of ERR $\alpha$ in $\mathrm{T}$ cells results in their inability to proliferate or differentiate into Th subsets, an effect, which is rescued for proliferation and Treg cell differentiation, but not Teffector differentiation, by addition of long chain fatty acids (123). Thus, ERR $\alpha$ functions in T cells to enable them to prepare for the metabolic demands of proliferation and differentiation into effector subsets by enhancing glucose uptake and mitochondrial biogenesis.

\section{PGC1 $\alpha$}

Peroxisome proliferator activated receptor $\gamma$ co-activator $1 \alpha$ $(\mathrm{PGC} 1 \alpha)$ is a transcriptional co-activator, a protein with ability to enhance transcription factor binding to genes, which has no specific DNA binding capability of its own. It has a central role in metabolism being the co-activator for multiple transcription factors involved in mitochondrial biogenesis (129) and glucose and fatty acid metabolism (130) and gluconeogenesis (131).

\section{LIVER X RECEPTOR}

Liver X receptors (LXRs) are receptors of the nuclear receptor family, which bind to endogenous oxysterols. LXRs have two isoforms, $\alpha$ and $\beta$. Both isoforms are expressed by CD4 T cells. These receptors heterodimerize with the retinoid $X$ receptor (RXR) and function to modulate cholesterol homeostasis by controlling genes involved in cholesterol and lipid metabolism including sterol regulatory element binding protein (SREBP) $(132,133)$. LXRs have potent effects on $\mathrm{T}$ cell function including inhibition of lymphocyte proliferation (132). Ectopic expression of LXR was also shown to inhibit $\mathrm{T}$ cell differentiation into Th17 cells via induction of srebp-1 a protein capable of inhibition of aryl hydrocarbon receptor (Ahr) binding to the IL-17 gene (134). Agonists of LXR have been shown to ameliorate experimental autoimmune encephalomyelitis (EAE) (134). SREBP-1 has recently been shown to be essential for coordinating $\mathrm{T}$ cell receptor activation and lipid anabolism in dividing CD8 T cells (135). In the absence of SREBP-1, CD8 T cells can enter G1 phase of cell cycle but fail to continue to mitosis due to a lack of sufficient cellular cholesterol.

\section{$\mathrm{Ca}^{2+}$ SignALING}

Calcium levels in the mitochondrial matrix are tightly regulated by mitochondrial $\mathrm{Ca}^{2+}$ uniporters (MCU), which transport $\mathrm{Ca}^{2+}$ across the inner mitochondrial membranes (136). Mitochondrial sequestration of $\mathrm{Ca}^{2+}$ ions results in positive feedback leading to activation of plasma membrane CRAC channels and sustained $\mathrm{T}$ cell activation $(137,138)$. $\mathrm{Ca}^{2+}$ concentration in the mitochondrial matrix also has important effects on the rate of the TCA cycle as three calcium dependent TCA enzymes: 2-oxyglutarate dehydrogenase, $\mathrm{NAD}^{+}$-isocitrate dehydrogenase, and pyruvate dehydrogenase are activated by $\mathrm{Ca}^{2+}$ ions leading to increased mitochondrial metabolism (139). 


\section{MITOGEN-ACTIVATED PROTEIN KINASE}

The MAPK family of serine/threonine/tyrosine kinases plays a central and pleitropic role in transducing diverse signals from the environment into nuclear transcription factor activation. They are involved in the cellular responses of $\mathrm{T}$ cells to inflammatory cytokines, mitogens, insulin, heat shock, and osmotic stress [reviewed in Ref. (140)]. MAPK is required for glucose and glutamine uptake and metabolism in T cells in a CD28 dependent manner and is required for glutaminase activity $(89,141)$.

\section{AMP ACTIVATED PROTEIN KINASE}

AMP activated protein kinase is important in energy homeostasis within the cell and the sensing of hypoxia due to the increase in AMP to ATP ratio under these conditions [reviewed in Ref. (142)]. The binding of AMP or ADP allows the phosphorylation of AMPK, which activated its serine/threonine kinase activity. AMPK phosporylates acetyl-Co-A carboxylase (ACC1) to inhibit its lipogenic activity and ACC2 to promote expression of carnitine palmitoyltransferase (CPT1A), which is the rate limiting factor for the uptake and oxidation of lipids in the mitochondria. PGC1 $\alpha$ activity (see above) is also promoted by AMPK activation. AMPK also inhibits TORC1 signaling by phosphorylating TSC1/2 and enhances autophagy, glucose uptake, and mitochondrial biogenesis. The net effect of AMPK activation is to shut down energy intensive processes and to activate pathways that replenish ATP levels within the cell.

\section{METABOLIC FEEDBACK AND "MOONLIGHTING" FUNCTIONS OF METABOLIC ENZYMES}

In addition to carrying out metabolic activities, many enzymes of the glycolytic, pentose phosphate, TCA, and fatty acid metabolism pathways have dual function and "moonlight" as RNA binding proteins, transcriptionally controlling their targets in a metabolite dependent fashion (Figure 5). This area has been well reviewed $(96,143,144)$ so only a few key examples will be highlighted here.

The most thoroughly investigated example of a metabolic enzyme having a second function in RNA translational control is cytosolic aconitase/iron regulatory protein $1-\operatorname{IRP} 1(145,146)$. This enzyme functions to convert citrate to isocitrate in the TCA cycle. It is dependent on replete levels of cellular iron for enzymatic function as it contains a cubane $4 \mathrm{fe}-4 \mathrm{~S}$ iron sulfur cluster responsible for its catalytic activity. In conditions of low iron this cluster disassembles and converts to IRP1, which is capable of binding to iron responsive elements (IREs), conserved hairpin structures in the $3^{\prime}$ UTR of RNAs responsible for iron homeostasis (147). IRP binds with very high affinity $(\mathrm{Kd} 5 \mathrm{pM})$ to transferrin receptor RNA (148) to protect the RNA from degradation and increase translation. It simultaneously binds to an IRE in ferritin, an iron storage protein, causing it to become translationally repressed (149). In this way, the enzymatic activity of the protein, dependent on iron senses cellular iron levels and acts as a rheostat for iron by adjusting the translation of RNA encoding proteins involved in iron homeostasis. Uptake of iron is also essential for the heme containing proteins in the electron transport chain, and would be required for resting Treg cells preferentially engaging FAO and OXPHOS.

Several enzymes of the glycolysis pathway have been shown to have RNA binding activity. Glyceraldehyde 3 phosphate

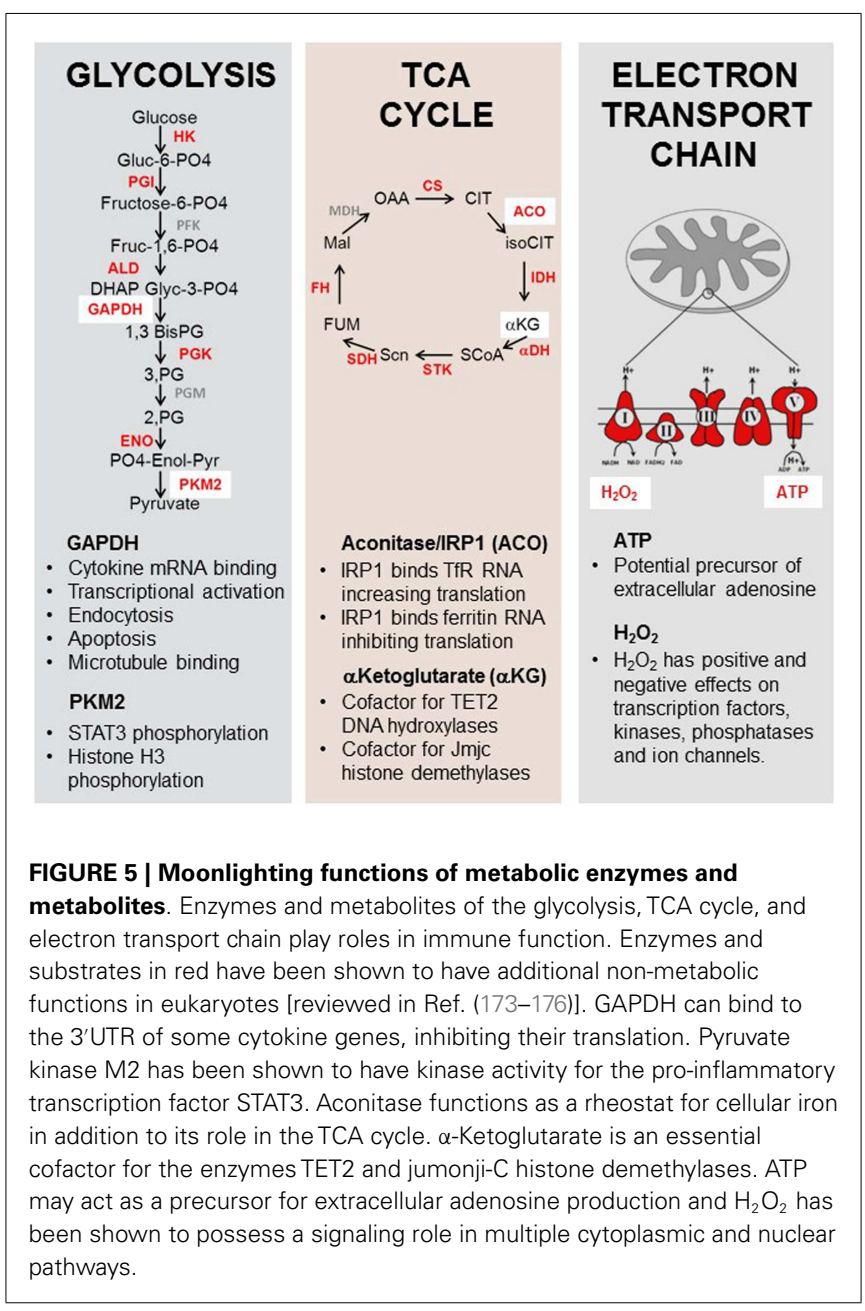

dehydrogenase (GAPDH), aldolase, lactate dehydrogenase (LDH), phosphoglycerate kinase (PGK), and glucose 6 phosphate dehydrogenase $(\mathrm{G} 6 \mathrm{PDH})$ have been shown to regulate the translation of immunologically relevant mRNA targets (150-152). GAPDH, LDH PGK, and G6PDH all share a dinucleotide binding region termed the Rossman fold (153). This RNA binding region consists of two $\beta \alpha \beta$ folds each of which binds a mononucleotide. The Rossman fold RNA binding activity is competed for by the dinucleotides $\mathrm{NAD}^{+}, \mathrm{NADH}$, and ATP. In the case of GAPDH, the cofactor $\mathrm{NAD}^{+}$is required for glycolytic activity and inhibits target RNA binding (150) In this way, when GAPDH is required for glycolysis and cofactors are abundant its RNA binding ability is competed for by cofactors and shut off. GAPDH has been shown to target many RNAs including mRNA (150), tRNA (154), rRNA (155), and viral RNAs (156). GAPDH mRNA targets include IL2, GM-CSF, IFN $\alpha$ (150), GLUT1 (151), and IFN- $\gamma$ (95) where it binds to an $\mathrm{AU}$ rich region in the $3^{\prime}$ untranslated region. In the case of IFN- $\gamma$, GAPDH comprises a component of the gamma interferon-activated inhibitor of translation (GAIT) complex (95). If activated $\mathrm{T}$ cells are deprived of glucose, and instead provided with galactose, then glycolysis cannot take place, and yet the T cells still activate and proliferate (because galactose provides alternative precursors for nucleotide synthesis via the pentose phosphate 
pathway), but now because GAPDH has no substrate, it blocks the translation of IFN- $\gamma$. Under these conditions the $\mathrm{T}$ cells also then express other markers of $\mathrm{T}$ cell exhaustion such as programed death 1 (PD-1) (95). The corollary of this is that inducing glycolysis, for example, by mTOR activation, will tend to promote effector cell differentiation. There are also suggestions that there may be other examples where metabolic enzymes, for example, hexokinase (157) and IDO (51) can have a secondary, signaling role, in DC differentiation.

Pyruvate kinase (PK) catalyzes the final step of glycolyis; phosphoenolpyruvate to pyruvate. It exists in two differentially spliced forms in most cells PKM1 and PKM2 (158). Highly proliferating cells including embryonic cells tumor cells and activated T cells preferentially express the less efficient form PKM2, which may support accumulation of glycolytic intermediates necessary for production of amino acids and nucleotides during proliferation $(96,159,160)$. PKM2 also "moonlights" as a kinase for STAT3 using PEP instead of ATP as a phosphate donor (161). This finding suggests that the metabolic status of the $\mathrm{T}$ cell, anabolic or catabolic, indirectly controls activity of a transcription factor known to transduce pro-inflammatory signals downstream of diverse cytokines including interferons, IL-5, IL-6, and leptin. Effector T cells in anabolic mode might be predicted to enhance transcriptional programs normally associated with these pro-inflammatory signals.

\section{Treg CELL EPIGENETICS AND METABOLISM}

Constitutive expression of FOXP3 has been shown to be essential for continued Treg cell maintenance of functional tolerance in vivo $(11,162-164)$. However, FOXP3 expression on its own does not seem to be sufficient to enable full differentiation into the Treg cell lineage. Mature Treg cells have a characteristic epigenetic "fingerprint" of demethylated genes associated with Treg cell function, which includes five genes termed the "Treg.me"; FOXP3, CTLA4, Ikzf2 (Helios), Ikzf4 (Eos), and Tnfrsf18 (GITR) (165, 166). In addition, several hundred proteins have been found to be associated with FOXP3 in mass spectroscopy screens (167) several of which are important for maintaining FOXP3 transcription. Several important transcription factors including Runx1, NFAT, and GATA3, which are necessary for FOXP3's function also associate with FOXP3. Importantly, progression along the Treg cell lineage seems to occur prior to the induction of FOXP3 as several characteristic Treg cell gene sets can be observed in $\mathrm{T}$ cells from mice with a targeted disruption of the FOXP3 gene into which GFP has been inserted under the control of the FOXP3 promoter. FOXP3 is thought to amplify the pre-existing gene profile (168). Characteristic epigenetic modifications have been shown to be associated with the FOXP3 gene in mature Treg cell, which are not present in naïve $\mathrm{T}$ cells. An intronic conserved non-coding element (CNS2) was discovered to be demethylated preferentially in stable Treg cells $(169,170)$. Histones surrounding this region were also shown to have characteristic modifications of open chromatin (H3K4me3 and acetyl H4 high) (169). DNA methylation and histone modification by methylation, acetylations, and phosphorylation via the action of methyl transferases, acetyl transferases, and kinases, respectively, requires cellular metabolites as enzymatic substrates (171). For example, the sirtuins (histone deacetylases) and poly ADP ribose polymerases (PARPs) require the coenzyme $\mathrm{NAD}^{+}$to function (172). In addition, the TET2 DNA hydroxylases, involved in demethylation of DNA and the jumonji-C (JmjC) histone demethylases involved in histone demethylation belong to a group of enzymes called the $\alpha$-ketoglutarate dependent enzymes, which require the TCA cycle metabolite $\alpha$-ketoglutarate to function in addition to ascorbate, oxygen, and iron. Both these classes of enzymes are inhibited by the TCA cycle intermediates fumarate and succinate. It is conceivable that epigenetic changes in Treg cells required for stability and reprograming to the Treg cell lineage may be influenced by the metabolic program that the cell adopts in response to environmental stimuli such as glucose or fatty acid availability.

\section{ARE REGULATORY T CELLS ADAPTED METABOLICALLY FOR CURRENT AND FUTURE MICROENVIRONMENTS?}

The experimental data of Treg cell metabolism are predominantly derived from in vitro observations of resting Treg cells. These cell cultures are usually performed in media with a vast molar excess of EAAs, 10-fold physiological levels of glucose and glutamine and oxygen concentrations in excess of physiological norms. However, it is well known that Treg cells proliferate vigorously in vivo and presumably require glycolytic intermediates to fuel anabolic demand during multiple rounds of mitosis. The question remains, what would be the advantage to non-proliferating Treg cells of adopting FAO and OXPHOS as a default metabolic mode? We hypothesize that Treg cells are uniquely adapted to their current and future in vivo environments. While Treg cells interact with DCs in a tolerant microenvironment they induce EAA-catabolizing enzyme expression in the DC, forming a zone of acute EAA starvation. In this situation their catabolic mode preferentially protects them from the effects of amino acid starvation, and presumably limiting glucose concentrations in inflamed environments. In addition, they receive survival signals in the form of IL-2 from effector T cells, yet produce little IL-2 themselves, thus, inhibiting further effector $\mathrm{T}$ cell proliferation. It is possible that shifting metabolism to catabolic mode in this situation frees up "moonlighting" glycolytic enzymes to suppress translation of pro-inflammatory cytokines by the Treg cells. Expansion of Treg cell numbers in the draining lymph nodes of inflammatory sites would elicit a switch to anabolic metabolism under conditions of sufficient glucose and glutamine, enabling increase in cell mass and mitosis. The ability to shift from an anabolic expansion mode to a catabolic suppression mode may be key to Treg cell function, and presents an attractive target for therapeutic intervention.

\section{CONCLUDING REMARKS}

Nutrient sensing and the coordination of metabolism seem to be inherently associated with the mechanisms of immune regulation in vivo. The question that then arises is - can any of these metabolic processes be specifically targeted for manipulating immune responses in transplantation, the treatment of autoimmune diseases and cancer immunotherapy? Many of these pathways are common to many different cells in the body and relying on the immunosuppressive effects of available drugs such as the mTOR inhibitors may therefore have a variety of unwanted side effects. Consequently, we need to look either for potential 
target components of these metabolic pathways that are restricted primarily to immune cells or for ways to amplify the effects of metabolic inhibitors such that they can be used at doses well below that which have effects outside the immune system. One way to achieve this might be to concentrate on the period of immune reconstitution after lymphocyte depletion when the metabolic needs of homeostatic proliferation of a small number of residual $\mathrm{T}$ cells could be biased in favor of regulatory $\mathrm{T}$ cells.

\section{ACKNOWLEDGMENTS}

Stephen Cobbold, Duncan Howie, and Herman Waldmann are supported by a European Research Council advanced investigator award ("PARIS").

\section{REFERENCES}

1. Fang Y, Vilella-Bach M, Bachmann R, Flanigan A, Chen J. Phosphatidic acidmediated mitogenic activation of mTOR signaling. Science (2001) 294:1942-5. doi:10.1126/science.1066015

2. Peter C, Waldmann H, Cobbold SP. mTOR signalling and metabolic regulation of T cell differentiation. Curr Opin Immunol (2010) 22:655-61. doi:10.1016/j.coi.2010.08.010

3. Warburg O. On respiratory impairment in cancer cells. Science (1956) 124:269-70.

4. Buttgereit F, Brand MD, Muller M. ConA induced changes in energy metabolism of rat thymocytes. Biosci Rep (1992) 12:381-6. doi:10.1007/BF02351215

5. Caro-Maldonado A, Gerriets VA, Rathmell JC. Matched and mismatched metabolic fuels in lymphocyte function. Semin Immunol (2012) 24:405-13. doi:10.1016/j.smim.2012.12.002

6. Wieman HL, Wofford JA, Rathmell JC. Cytokine stimulation promotes glucose uptake via phosphatidylinositol-3 kinase/Akt regulation of Glut1 activity and trafficking. Mol Biol Cell (2007) 18:1437-46. doi:10.1091/mbc.E06-07-0593

7. Zheng Y, Collins SL, Lutz MA, Allen AN, Kole TP, Zarek PE, et al. A role for mammalian target of rapamycin in regulating $\mathrm{T}$ cell activation versus anergy. J Immunol (2007) 178:2163-70. doi:10.4049/jimmunol.178.4.2163

8. Fingar DC, Salama S, Tsou C, Harlow E, Blenis J. Mammalian cell size is controlled by mTOR and its downstream targets S6K1 and 4EBP1/eIF4E. Genes Dev (2002) 16:1472-87. doi:10.1101/gad.995802

9. Akimova T, Kamath BM, Goebel JW, Meyers KE, Rand EB, Hawkins A, et al. Differing effects of rapamycin or calcineurin inhibitor on T-regulatory cells in pediatric liver and kidney transplant recipients. Am J Transpl (2012) 12:3449-61. doi:10.1111/j.1600-6143.2012.04269.x

10. Waldmann H, Adams E, Fairchild P, Cobbold S. Infectious tolerance and the long-term acceptance of transplanted tissue. Immunol Rev (2006) 212:301-13. doi:10.1111/j.0105-2896.2006.00406.x

11. Kendal AR, Chen Y, Regateiro FS, Ma J, Adams E, Cobbold SP, et al. Sustained suppression by FOXP3 + regulatory T cells is vital for infectious transplantation tolerance. J Exp Med (2011) 208:2043-53. doi:10.1084/jem.20110767

12. Cobbold SP, Castejon R, Adams E, Zelenika D, Graca L, Humm S, et al. Induction of foxP3+ regulatory $\mathrm{T}$ cells in the periphery of $\mathrm{T}$ cell receptor transgenic mice tolerized to transplants. J Immunol (2004) 172:6003-10. doi:10.4049/jimmunol.172.10.6003

13. Graca L, Cobbold SP, Waldmann H. Identification of regulatory T cells in tolerated allografts. J Exp Med (2002) 195:1641-6. doi:10.1084/jem.20012097

14. Cobbold SP, Nolan KF, Graca L, Castejon R, Le Moine A, Frewin M, et al. Regulatory T cells and dendritic cells in transplantation tolerance: molecular markers and mechanisms. Immunol Rev (2003) 196:109-24. doi:10.1046/j. 1600-065X.2003.00078.x

15. Farquhar CA, Paterson AM, Cobbold SP, Garcia Rueda H, Fairchild PJ, Yates SF, et al. Tolerogenicity is not an absolute property of a dendritic cell. Eur $J$ Immunol (2010) 40:1728-37. doi:10.1002/eji.200939974

16. Cobbold SP, Adams E, Waldmann H. Biomarkers of transplantation tolerance: more hopeful than helpful? Front Immunol (2011) 2:9. doi:10.3389/fimmu. 2011.00009

17. Cobbold SP, Adams E, Farquhar CA, Nolan KF, Howie D, Lui KO, et al. Infectious tolerance via the consumption of essential amino acids and mTOR signaling. Proc Natl Acad Sci U S A (2009) 106:12055-60. doi:10.1073/pnas. 0903919106

18. Sinclair LV, Rolf J, Emslie E, Shi YB, Taylor PM, Cantrell DA. Control of amino-acid transport by antigen receptors coordinates the metabolic reprogramming essential for T cell differentiation. Nat Immunol (2013) 14:500-8. doi:10.1038/ni.2556

19. Munn DH, Zhou M, Attwood JT, Bondarev I, Conway SJ, Marshall B, et al. Prevention of allogeneic fetal rejection by tryptophan catabolism. Science (1998) 281:1191-3. doi:10.1126/science.281.5380.1191

20. Fallarino F, Grohmann U, Vacca C, Bianchi R, Orabona C, Spreca A, et al. T cell apoptosis by tryptophan catabolism. Cell Death Differ (2002) 9:1069-77. doi:10.1038/sj.cdd.4401073

21. Munn DH, Sharma MD, Baban B, Harding HP, Zhang Y, Ron D, et al. GCN2 kinase in $\mathrm{T}$ cells mediates proliferative arrest and anergy induction in response to indoleamine 2,3-dioxygenase. Immunity (2005) 22:633-42. doi:10.1016/j.immuni.2005.03.013

22. Metz R, Rust S, Duhadaway JB, Mautino MR, Munn DH, Vahanian NN, et al. IDO inhibits a tryptophan sufficiency signal that stimulates mTOR: a novel IDO effector pathway targeted by D-1-methyl-tryptophan. Oncoimmunology (2012) 1:1460-8. doi:10.4161/onci.21716

23. Zelenika D, Adams E, Humm S, Lin CY, Waldmann H, Cobbold SP. The role of CD4+ T-cell subsets in determining transplantation rejection or tolerance. Immunol Rev (2001) 182:164-79. doi:10.1034/j.1600-065X.2001.1820113.x

24. Nowak EC, De Vries VC, Wasiuk A, Ahonen C, Bennett KA, Le Mercier I, et al. Tryptophan hydroxylase-1 regulates immune tolerance and inflammation. J Exp Med (2012) 209:2127-35. doi:10.1084/jem.20120408

25. Kropf P, Baud D, Marshall SE, Munder M, Mosley A, Fuentes JM, et al. Arginase activity mediates reversible $\mathrm{T}$ cell hyporesponsiveness in human pregnancy. Eur J Immunol (2007) 37:935-45. doi:10.1002/eji.200636542

26. Chabtini L, Mfarrej B, Mounayar M, Zhu B, Batal I, Dakle PJ, et al. TIM-3 regulates innate immune cells to induce fetomaternal tolerance. J Immunol (2013) 190:88-96. doi:10.4049/jimmunol.1202176

27. Lumeng CN, Bodzin JL, Saltiel AR. Obesity induces a phenotypic switch in adipose tissue macrophage polarization. J Clin Invest (2007) 117:175-84. doi:10.1172/JCI29881

28. Boulland ML, Marquet J, Molinier-Frenkel V, Moller P, Guiter C, Lasoudris F, et al. Human IL4I1 is a secreted L-phenylalanine oxidase expressed by mature dendritic cells that inhibits T-lymphocyte proliferation. Blood (2007) 110:220-7. doi:10.1182/blood-2006-07-036210

29. Qin S, Cobbold SP, Pope H, Elliott J, Kioussis D, Davies J, et al. "Infectious" transplantation tolerance. Science (1993) 259:974-7. doi:10.1126/science. 8094901

30. Schieke SM, Phillips D, McCoy JP Jr, Aponte AM, Shen RF, Balaban RS, et al. The mammalian target of rapamycin (mTOR) pathway regulates mitochondrial oxygen consumption and oxidative capacity. J Biol Chem (2006) 281:27643-52. doi:10.1074/jbc.M603536200

31. Loewith R, Jacinto E, Wullschleger S, Lorberg A, Crespo JL, Bonenfant D, et al. Two TOR complexes, only one of which is rapamycin sensitive, have distinct roles in cell growth control. Mol Cell (2002) 10:457-68. doi:10.1016/S10972765(02)00636-6

32. Laplante M, Sabatini DM. mTOR signaling at a glance. J Cell Sci (2009) 122:3589-94. doi:10.1242/jcs.051011

33. Sancak Y, Peterson TR, Shaul YD, Lindquist RA, Thoreen CC, Bar-Peled L, et al. The Rag GTPases bind raptor and mediate amino acid signaling to mTORC1. Science (2008) 320:1496-501. doi:10.1126/science.1157535

34. Sancak Y, Bar-Peled L, Zoncu R, Markhard AL, Nada S, Sabatini DM. RagulatorRag complex targets mTORC1 to the lysosomal surface and is necessary for its activation by amino acids. Cell (2010) 141:290-303. doi:10.1016/j.cell.2010. 02.024

35. Sabatini DM, Erdjument-Bromage H, Lui M, Tempst P, Snyder SH. RAFT1: a mammalian protein that binds to FKBP12 in a rapamycin-dependent fashion and is homologous to yeast TORs. Cell (1994) 78:35-43. doi:10.1016/00928674(94) $90570-3$

36. Niles BJ, Joslin AC, Fresques T, Powers T. TOR complex 2-Ypk1 signaling maintains sphingolipid homeostasis by sensing and regulating ROS accumulation. Cell Rep (2014) 6:541-52. doi:10.1016/j.celrep.2013.12.040

37. Cohen A, Kupiec M, Weisman R. Glucose activates TORC2-Gad8 via positive regulation of the cAMP/PKA pathway and negative regulation of the 
Pmk1-MAPK pathway. J Biol Chem (2014) 289(31):21727-37. doi:10.1074/ jbc.M114.573824

38. Liu P, Gan W, Inuzuka H, Lazorchak AS, Gao D, Arojo O, et al. Sin1 phosphorylation impairs mTORC2 complex integrity and inhibits downstream Akt signalling to suppress tumorigenesis. Nat Cell Biol (2013) 15:1340-50. doi:10.1038/ncb2860

39. Sarbassov DD, Ali SM, Sengupta S, Sheen JH, Hsu PP, Bagley AF, et al. Prolonged rapamycin treatment inhibits mTORC2 assembly and Akt/PKB. Mol Cell (2006) 22:159-68. doi:10.1016/j.molcel.2006.03.029

40. Tato I, Bartrons R, Ventura F, Rosa JL. Amino acids activate mammalian target of rapamycin complex 2 (mTORC2) via PI3K/Akt signaling. J Biol Chem (2011) 286:6128-42. doi:10.1074/jbc.M110.166991

41. Charest PG, Shen Z, Lakoduk A, Sasaki AT, Briggs SP, Firtel RA. A Ras signaling complex controls the RasC-TORC2 pathway and directed cell migration. Dev Cell (2010) 18:737-49. doi:10.1016/j.devcel.2010.03.017

42. Kuo CJ, Chung J, Fiorentino DF, Flanagan WM, Blenis J, Crabtree GR. Rapamycin selectively inhibits interleukin-2 activation of p70 S6 kinase. Nature (1992) 358:70-3. doi:10.1038/358070a0

43. Delgoffe GM, Kole TP, Zheng Y, Zarek PE, Matthews KL, Xiao B, et al. The mTOR kinase differentially regulates effector and regulatory $\mathrm{T}$ cell lineage commitment. Immunity (2009) 30:832-44. doi:10.1016/j.immuni. 2009.04.014

44. Haxhinasto S, Mathis D, Benoist C. The AKT-mTOR axis regulates de novo differentiation of CD4+FOXP3+ cells. J Exp Med (2008) 205:565-74. doi:10.1084/jem.20071477

45. Sauer S, Bruno L, Hertweck A, Finlay D, Leleu M, Spivakov M, et al. T cell receptor signaling controls FOXP3 expression via PI3K, Akt, and mTOR. Proc Natl Acad Sci U S A (2008) 105:7797-802. doi:10.1073/pnas.0800928105

46. Liu G, Burns S, Huang G, Boyd K, Proia RL, Flavell RA, et al. The receptor S1P1 overrides regulatory $\mathrm{T}$ cell-mediated immune suppression through AktmTOR. Nat Immunol (2009) 10:769-77. doi:10.1038/ni.1743

47. Mandala S, Hajdu R, Bergstrom J, Quackenbush E, Xie J, Milligan J, et al. Alteration of lymphocyte trafficking by sphingosine-1-phosphate receptor agonists. Science (2002) 296:346-9. doi:10.1126/science.1070238

48. Sehrawat S, Rouse BT. Anti-inflammatory effects of FTY720 against viralinduced immunopathology: role of drug-induced conversion of $\mathrm{T}$ cells to become FOXP3+ regulators. J Immunol (2008) 180:7636-47. doi:10.4049/ jimmunol.180.11.7636

49. Kim JH, Kim JE, Liu HY, Cao W, Chen J. Regulation of interleukin-6-induced hepatic insulin resistance by mammalian target of rapamycin through the STAT3-SOCS3 pathway. J Biol Chem (2008) 283:708-15. doi:10.1074/jbc. M708568200

50. Qin H, Wang L, Feng T, Elson CO, Niyongere SA, Lee SJ, et al. TGF-beta promotes Th17 cell development through inhibition of SOCS3. J Immunol (2009) 183:97-105. doi:10.4049/jimmunol.0801986

51. Pallotta MT, Orabona C, Volpi C, Vacca C, Belladonna ML, Bianchi R, et al. Indoleamine 2,3-dioxygenase is a signaling protein in long-term tolerance by dendritic cells. Nat Immunol (2011) 12:870-8. doi:10.1038/ni.2077

52. Yang XP, Ghoreschi K, Steward-Tharp SM, Rodriguez-Canales J, Zhu J, Grainger JR, et al. Opposing regulation of the locus encoding IL-17 through direct, reciprocal actions of STAT3 and STAT5. Nat Immunol (2011) 12:247-54. doi:10.1038/ni.1995

53. Harada Y, Harada Y, Elly C, Ying G, Paik JH, Depinho RA, et al. Transcription factors Foxo3a and Foxol couple the E3 ligase Cbl-b to the induction of FOXP3 expression in induced regulatory T cells. J Exp Med (2010) 207:1381-91. doi:10.1084/jem.20100004

54. Ouyang W, Beckett O, Ma Q, Paik JH, Depinho RA, Li MO. Foxo proteins cooperatively control the differentiation of FOXP3+ regulatory T cells. Nat Immunol (2010) 11:618-27. doi:10.1038/ni.1884

55. Zhang Q, Cui F, Fang L, Hong J, Zheng B, Zhang JZ. TNF-alpha impairs differentiation and function of TGF-beta-induced Treg cells in autoimmune diseases through Akt and Smad3 signaling pathway. J Mol Cell Biol (2013) 5:85-98. doi:10.1093/jmcb/mjs063

56. Lee K, Gudapati P, Dragovic S, Spencer C, Joyce S, Killeen N, et al. Mammalian target of rapamycin protein complex 2 regulates differentiation of Th1 and Th2 cell subsets via distinct signaling pathways. Immunity (2010) 32:743-53. doi:10.1016/j.immuni.2010.06.002
57. Kopf H, De La Rosa GM, Howard OM, Chen X. Rapamycin inhibits differentiation of Th17 cells and promotes generation of FoxP3+ T regulatory cells. Int Immunopharmacol (2007) 7:1819-24. doi:10.1016/j.intimp.2007.08.027

58. Zeng H, Yang K, Cloer C, Neale G, Vogel P, Chi H. mTORC1 couples immune signals and metabolic programming to establish T-cell function. Nature (2013) 499:485-90. doi:10.1038/nature12297

59. Procaccini C, De Rosa V, Galgani M, Abanni L, Cali G, Porcellini A, et al. An oscillatory switch in mTOR kinase activity sets regulatory $\mathrm{T}$ cell responsiveness. Immunity (2010) 33:929-41. doi:10.1016/j.immuni.2010.11.024

60. Ben-Shoshan J, Maysel-Auslender S, Mor A, Keren G, George J. Hypoxia controls CD4+CD25+ regulatory T-cell homeostasis via hypoxia-inducible factorlalpha. Eur J Immunol (2008) 38:2412-8. doi:10.1002/eji.200838318

61. Clambey ET, McNamee EN, Westrich JA, Glover LE, Campbell EL, Jedlicka P, et al. Hypoxia-inducible factor-1 alpha-dependent induction of FoxP3 drives regulatory T-cell abundance and function during inflammatory hypoxia of the mucosa. Proc Natl Acad Sci U S A (2012) 109:E2784-93. doi:10.1073/pnas. 1202366109

62. Dang EV, Barbi J, Yang HY, Jinasena D, Yu H, Zheng Y, et al. Control of $\mathrm{T}(\mathrm{H}) 17 / \mathrm{T}(\mathrm{reg})$ balance by hypoxia-inducible factor 1. Cell (2011) 146:772-84. doi:10.1016/j.cell.2011.07.033

63. Shi LZ, Wang R, Huang G, Vogel P, Neale G, Green DR, et al. HIFlalphadependent glycolytic pathway orchestrates a metabolic checkpoint for the differentiation of TH17 and Treg cells. J Exp Med (2011) 208:1367-76. doi:10.1084/jem.20110278

64. Jung YJ, Isaacs JS, Lee S, Trepel J, Neckers L. IL-1beta-mediated up-regulation of HIF-1alpha via an NFkappaB/COX-2 pathway identifies HIF-1 as a critical link between inflammation and oncogenesis. FASEB J (2003) 17:2115-7. doi:10.1096/fj.03-0329fje

65. Safran M, Kaelin WG Jr. HIF hydroxylation and the mammalian oxygensensing pathway. JClin Invest (2003) 111:779-83. doi:10.1172/JCI18181

66. Brugarolas J, Lei K, Hurley RL, Manning BD, Reiling JH, Hafen E, et al. Regulation of mTOR function in response to hypoxia by REDD1 and the TSC1/TSC2 tumor suppressor complex. Genes Dev (2004) 18:2893-904. doi:10.1101/gad.1256804

67. Hardie DG. Minireview: the AMP-activated protein kinase cascade: the key sensor of cellular energy status. Endocrinology (2003) 144:5179-83. doi:10. 1210/en.2003-0982

68. Inoki K, Zhu T, Guan KL. TSC2 mediates cellular energy response to control cell growth and survival. Cell (2003) 115:577-90. doi:10.1016/S0092-8674(03) 00929-2

69. Regateiro FS, Howie D, Nolan KF, Agorogiannis EI, Greaves DR, Cobbold SP, et al. Generation of anti-inflammatory adenosine by leukocytes is regulated by TGF-beta. Eur J Immunol (2011) 41:2955-65. doi:10.1002/eji.201141512

70. Deaglio S, Dwyer KM, Gao W, Friedman D, Usheva A, Erat A, et al. Adenosine generation catalyzed by CD39 and CD73 expressed on regulatory T cells mediates immune suppression. J Exp Med (2007) 204:1257-65. doi:10.1084/ jem. 20062512

71. Sitkovsky M, Lukashev D, Deaglio S, Dwyer K, Robson SC, Ohta A. Adenosine A2A receptor antagonists: blockade of adenosinergic effects and $\mathrm{T}$ regulatory cells. Br J Pharmacol (2008) 153(Suppl 1):S457-64. doi:10.1038/bjp.2008.23

72. Ohtsuka T, Changelian PS, Bouis D, Noon K, Harada H, Lama VN, et al. Ecto5 '-nucleotidase (CD73) attenuates allograft airway rejection through adenosine 2A receptor stimulation. J Immunol (2010) 185:1321-9. doi:10.4049/ jimmunol.0901847

73. Apasov SG, Sitkovsky MV. The extracellular versus intracellular mechanisms of inhibition of TCR-triggered activation in thymocytes by adenosine under conditions of inhibited adenosine deaminase. Int Immunol (1999) 11:179-89.

74. Sun X, Wu Y, Gao W, Enjyoji K, Csizmadia E, Muller CE, et al. CD39/ENTPD1 expression by $\mathrm{CD} 4+\mathrm{FOXP} 3+$ regulatory $\mathrm{T}$ cells promotes hepatic metastatic tumor growth in mice. Gastroenterology (2010) 139:1030-40. doi:10.1053/j. gastro.2010.05.007

75. Clayton A, Al-Taei S, Webber J, Mason MD, Tabi Z. Cancer exosomes express $\mathrm{CD} 39$ and $\mathrm{CD} 73$, which suppress $\mathrm{T}$ cells through adenosine production. J Immunol (2011) 187:676-83. doi:10.4049/jimmunol.1003884

76. Bental M, Deutsch C. Metabolic changes in activated T cells: an NMR study of human peripheral blood lymphocytes. Magn Reson Med (1993) 29:317-26. doi:10.1002/mrm.1910290307 
77. Fox CJ, Hammerman PS, Thompson CB. Fuel feeds function: energy metabolism and the T-cell response. Nat Rev Immunol (2005) 5:844-52. doi:10.1038/ nri1710

78. Michalek RD, Gerriets VA, Jacobs SR, Macintyre AN, Maciver NJ, Mason EF, et al. Cutting edge: distinct glycolytic and lipid oxidative metabolic programs are essential for effector and regulatory CD4+ T cell subsets. J Immunol (2011) 186:3299-303. doi:10.4049/jimmunol.1003613

79. Yoon H, Kim TS, Braciale TJ. The cell cycle time of CD8+ T cells responding in vivo is controlled by the type of antigenic stimulus. PLoS One (2010) 5:e15423. doi:10.1371/journal.pone.0015423

80. Kim JW, Dang CV. Cancer's molecular sweet tooth and the Warburg effect. Cancer Res (2006) 66:8927-30. doi:10.1158/0008-5472.CAN-06-1501

81. Frauwirth KA, Riley JL, Harris MH, Parry RV, Rathmell JC, Plas DR, et al. The CD28 signaling pathway regulates glucose metabolism. Immunity (2002) 16:769-77. doi:10.1016/S1074-7613(02)00323-0

82. Jacobs SR, Herman CE, Maciver NJ, Wofford JA, Wieman HL, Hammen JJ, et al. Glucose uptake is limiting in T cell activation and requires CD28-mediated Akt-dependent and independent pathways. J Immunol (2008) 180:4476-86. doi:10.4049/jimmunol.180.7.4476

83. Roos D, Loos JA. Changes in the carbohydrate metabolism of mitogenically stimulated human peripheral lymphocytes. II. Relative importance of glycolysis and oxidative phosphorylation on phytohaemagglutinin stimulation. Exp Cell Res (1973) 77:127-35. doi:10.1016/0014-4827(73)90561-2

84. Wang R, Dillon CP, Shi LZ, Milasta S, Carter R, Finkelstein D, et al. The transcription factor Myc controls metabolic reprogramming upon T lymphocyte activation. Immunity (2011) 35:871-82. doi:10.1016/j.immuni.2011.09.021

85. Bergstrom J, Furst P, Noree LO, Vinnars E. Intracellular free amino acid concentration in human muscle tissue. J Appl Physiol (1974) 36:693-7.

86. Calder PC, Yaqoob P. Glutamine and the immune system. Amino Acids (1999) 17:227-41. doi:10.1007/BF01366922

87. Ardawi MS, Newsholme EA. Glutamine metabolism in lymphocytes of the rat. Biochem J (1983) 212:835-42.

88. Ardawi MS. Glutamine and glucose metabolism in human peripheral lymphocytes. Metabolism (1988) 37:99-103. doi:10.1016/0026-0495(88)90036-4

89. Carr EL, Kelman A, Wu GS, Gopaul R, Senkevitch E, Aghvanyan A, et al. Glutamine uptake and metabolism are coordinately regulated by ERK/MAPK during T lymphocyte activation. J Immunol (2010) 185:1037-44. doi:10.4049/ jimmunol.0903586

90. Nakaya M, Xiao Y, Zhou X, Chang JH, Chang M, Cheng X, et al. Inflammatory $\mathrm{T}$ cell responses rely on amino acid transporter ASCT2 facilitation of glutamine uptake and mTORC1 kinase activation. Immunity (2014) 40:692-705. doi:10.1016/j.immuni.2014.04.007

91. Csibi A, Fendt SM, Li C, Poulogiannis G, Choo AY, Chapski DJ, et al. The mTORC1 pathway stimulates glutamine metabolism and cell proliferation by repressing SIRT4. Cell (2013) 153:840-54. doi:10.1016/j.cell.2013.04.023

92. Le A, Lane AN, Hamaker M, Bose S, Gouw A, Barbi J, et al. Glucose-independent glutamine metabolism via TCA cycling for proliferation and survival in B cells. Cell Metab (2012) 15:110-21. doi:10.1016/j.cmet.2011.12.009

93. Metallo CM, Gameiro PA, Bell EL, Mattaini KR, Yang J, Hiller K, et al. Reductive glutamine metabolism by IDH1 mediates lipogenesis under hypoxia. Nature (2012) 481:380-4. doi:10.1038/nature10602

94. van der Windt GJ, Everts B, Chang CH, Curtis JD, Freitas TC, Amiel E, et al. Mitochondrial respiratory capacity is a critical regulator of CD8+ T cell memory development. Immunity (2012) 36:68-78. doi:10.1016/j.immuni. 2011.12.007

95. Chang CH, Curtis JD, Maggi LB Jr, Faubert B, Villarino AV, O’Sullivan D, et al. Posttranscriptional control of $\mathrm{T}$ cell effector function by aerobic glycolysis. Cell (2013) 153:1239-51. doi:10.1016/j.cell.2013.05.016

96. Pearce EL, Poffenberger MC, Chang CH, Jones RG. Fueling immunity: insights into metabolism and lymphocyte function. Science (2013) 342:1242454. doi:10.1126/science. 1242454

97. Lei J, Hasegawa H, Matsumoto T, Yasukawa M. Peroxisome proliferatoractivated receptor alpha and gamma agonists together with TGF-beta convert human CD4+CD25- T cells into functional FOXP3+ regulatory T cells. J Immunol (2010) 185:7186-98. doi:10.4049/jimmunol.1001437

98. Jay MA, Ren J. Peroxisome proliferator-activated receptor (PPAR) in metabolic syndrome and type 2 diabetes mellitus. Curr Diabetes Rev (2007) 3:33-9. doi:10.2174/157339907779802067
99. Kleinewietfeld M, Manzel A, Titze J, Kvakan H, Yosef N, Linker RA, et al. Sodium chloride drives autoimmune disease by the induction of pathogenic TH17 cells. Nature (2013) 496:518-22. doi:10.1038/nature11868

100. Wu C, Yosef N, Thalhamer T, Zhu C, Xiao S, Kishi Y, et al. Induction of pathogenic TH17 cells by inducible salt-sensing kinase SGK1. Nature (2013) 496:513-7. doi:10.1038/nature11984

101. Garcia-Martinez JM, Alessi DR. mTOR complex 2 (mTORC2) controls hydrophobic motif phosphorylation and activation of serum- and glucocorticoid-induced protein kinase 1 (SGK1). Biochem J (2008) 416: 375-85. doi:10.1042/BJ20081668

102. Heikamp EB, Patel CH, Collins S, Waickman A, Oh MH, Sun IH, et al. The AGC kinase SGK1 regulates TH1 and TH2 differentiation downstream of the mTORC2 complex. Nat Immunol (2014) 15:457-64. doi:10.1038/ni.2867

103. Go WY, Liu X, Roti MA, Liu F, Ho SN. NFAT5/TonEBP mutant mice define osmotic stress as a critical feature of the lymphoid microenvironment. Proc Natl Acad Sci U S A (2004) 101:10673-8. doi:10.1073/pnas.0403139101

104. Machnik A, Neuhofer W, Jantsch J, Dahlmann A, Tammela T, Machura K, et al. Macrophages regulate salt-dependent volume and blood pressure by a vascular endothelial growth factor-C-dependent buffering mechanism. Nat Med (2009) 15:545-52. doi: $10.1038 / \mathrm{nm} .1960$

105. Friedman JM, Halaas JL. Leptin and the regulation of body weight in mammals. Nature (1998) 395:763-70. doi:10.1038/27376

106. La Cava A, Matarese G. The weight of leptin in immunity. Nature Reviews Immunology (2004) 4:371-9. doi:10.1038/nri1350

107. De Rosa V, Procaccini C, Cali G, Pirozzi G, Fontana S, Zappacosta S, et al. A key role of leptin in the control of regulatory T cell proliferation. Immunity (2007) 26:241-55. doi:10.1016/j.immuni.2007.01.011

108. Saucillo DC, Gerriets VA, Sheng J, Rathmell JC, Maciver NJ. Leptin metabolically licenses $\mathrm{T}$ cells for activation to link nutrition and immunity. J Immunol (2014) 192:136-44. doi:10.4049/jimmunol.1301158

109. Lord GM, Matarese G, Howard JK, Baker RJ, Bloom SR, Lechler RI. Leptin modulates the T-cell immune response and reverses starvation-induced immunosuppression. Nature (1998) 394:897-901. doi:10.1038/29795

110. Mandel MA, Mahmoud AA. Impairment of cell-mediated immunity in mutation diabetic mice (db/db). J Immunol (1978) 120:1375-7.

111. Chandra RK. Cell-mediated immunity in genetically obese C57BL/6J ob/ob) mice. Am J Clin Nutr (1980) 33:13-6.

112. Eilers M, Eisenman RN. Myc's broad reach. Genes Dev (2008) 22:2755-66. doi:10.1101/gad.1712408

113. Kim J, Woo AJ, Chu J, Snow JW, Fujiwara Y, Kim CG, et al. A Myc network accounts for similarities between embryonic stem and cancer cell transcription programs. Cell (2010) 143:313-24. doi:10.1016/j.cell.2010.09.010

114. Kim JW, Zeller KI, Wang Y, Jegga AG, Aronow BJ, O’Donnell KA, et al. Evaluation of myc E-box phylogenetic footprints in glycolytic genes by chromatin immunoprecipitation assays. Mol Cell Biol (2004) 24:5923-36. doi:10.1128/ MCB.24.13.5923-5936.2004

115. Wise DR, Deberardinis RJ, Mancuso A, Sayed N, Zhang XY, Pfeiffer HK, et al. Myc regulates a transcriptional program that stimulates mitochondrial glutaminolysis and leads to glutamine addiction. Proc Natl Acad Sci U S A (2008) 105:18782-7. doi:10.1073/pnas.0810199105

116. Dang CV, Le A, Gao P. MYC-induced cancer cell energy metabolism and therapeutic opportunities. Clin Cancer Res (2009) 15:6479-83. doi:10.1158/10780432.CCR-09-0889

117. Morrish F, Giedt C, Hockenbery D. c-Myc apoptotic function is mediated by NRF-1 target genes. Genes Dev (2003) 17:240-55. doi:10.1101/gad.1032503

118. Li F, Wang Y, Zeller KI, Potter JJ, Wonsey DR, O’Donnell KA, et al. Myc stimulates nuclearly encoded mitochondrial genes and mitochondrial biogenesis. Mol Cell Biol (2005) 25:6225-34. doi:10.1128/MCB.25.14.62256234.2005

119. Kim J, Lee JH, Iyer VR. Global identification of Myc target genes reveals its direct role in mitochondrial biogenesis and its E-box usage in vivo. PLoS One (2008) 3:e1798. doi:10.1371/journal.pone.0001798

120. O’Donnell KA, Yu D, Zeller KI, Kim JW, Racke F, Thomas-Tikhonenko A, et al. Activation of transferrin receptor 1 by c-Myc enhances cellular proliferation and tumorigenesis. Mol Cell Biol (2006) 26:2373-86. doi:10.1128/MCB.26.6. 2373-2386.2006

121. Giguere V. To ERR in the estrogen pathway. Trends Endocrinol Metab (2002) 13:220-5. doi:10.1016/S1043-2760(02)00592-1 
122. Greschik H, Wurtz JM, Sanglier S, Bourguet W, Van Dorsselaer A, Moras D, et al. Structural and functional evidence for ligand-independent transcriptional activation by the estrogen-related receptor 3. Mol Cell (2002) 9:303-13. doi:10.1016/S1097-2765(02)00444-6

123. Michalek RD, Gerriets VA, Nichols AG, Inoue M, Kazmin D, Chang CY, et al. Estrogen-related receptor-alpha is a metabolic regulator of effector T-cell activation and differentiation. Proc Natl Acad Sci U S A (2011) 108:18348-53. doi:10.1073/pnas.1108856108

124. Kallen J, Schlaeppi JM, Bitsch F, Filipuzzi I, Schilb A, Riou V, et al. Evidence for ligand-independent transcriptional activation of the human estrogenrelated receptor alpha (ERRalpha): crystal structure of ERRalpha ligand binding domain in complex with peroxisome proliferator-activated receptor coactivator-1alpha. J Biol Chem (2004) 279:49330-7. doi:10.1074/jbc. M407999200

125. Villena JA, Kralli A. ERRalpha: a metabolic function for the oldest orphan. Trends Endocrinol Metab (2008) 19:269-76. doi:10.1016/j.tem.2008.07.005

126. Carascossa S, Gobinet J, Georget V, Lucas A, Badia E, Castet A, et al. Receptorinteracting protein 140 is a repressor of the androgen receptor activity. Mol Endocrinol (2006) 20:1506-18. doi:10.1210/me.2005-0286

127. Christian M, White R, Parker MG. Metabolic regulation by the nuclear receptor corepressor RIP140. Trends Endocrinol Metab (2006) 17:243-50. doi:10.1016/j.tem.2006.06.008

128. Powelka AM, Seth A, Virbasius JV, Kiskinis E, Nicoloro SM, Guilherme A, et al. Suppression of oxidative metabolism and mitochondrial biogenesis by the transcriptional corepressor RIP140 in mouse adipocytes. J Clin Invest (2006) 116:125-36. doi:10.1172/JCI26040

129. Wu Z, Puigserver P, Andersson U, Zhang C, Adelmant G, Mootha V, et al. Mechanisms controlling mitochondrial biogenesis and respiration through the thermogenic coactivator PGC-1. Cell (1999) 98:115-24. doi:10.1016/S00928674(00)80611-X

130. Vega RB, Huss JM, Kelly DP. The coactivator PGC-1 cooperates with peroxisome proliferator-activated receptor alpha in transcriptional control of nuclear genes encoding mitochondrial fatty acid oxidation enzymes. Mol Cell Biol (2000) 20:1868-76. doi:10.1128/MCB.20.5.1868-1876.2000

131. Puigserver P, Rhee J, Donovan J, Walkey CJ, Yoon JC, Oriente F, et al. Insulinregulated hepatic gluconeogenesis through FOXO1-PGC-1alpha interaction. Nature (2003) 423:550-5. doi:10.1038/nature01667

132. Bensinger SJ, Bradley MN, Joseph SB, Zelcer N, Janssen EM, Hausner MA, et al. LXR signaling couples sterol metabolism to proliferation in the acquired immune response. Cell (2008) 134:97-111. doi:10.1016/j.cell.2008.04.052

133. Tontonoz P, Mangelsdorf DJ. Liver X receptor signaling pathways in cardiovascular disease. Mol Endocrinol (2003) 17:985-93. doi:10.1210/me.2003-0061

134. Cui G, Qin X, Wu L, Zhang Y, Sheng X, Yu Q, et al. Liver X receptor (LXR) mediates negative regulation of mouse and human Th17 differentiation. JClin Invest (2011) 121:658-70. doi:10.1172/JCI42974

135. Kidani Y, Elsaesser H, Hock MB, Vergnes L, Williams KJ, Argus JP, et al. Sterol regulatory element-binding proteins are essential for the metabolic programming of effector T cells and adaptive immunity. Nat Immunol (2013) 14:489-99. doi:10.1038/ni.2570

136. Kirichok Y, Krapivinsky G, Clapham DE. The mitochondrial calcium uniporter is a highly selective ion channel. Nature (2004) 427:360-4. doi:10.1038/ nature 02246

137. Gilabert JA, Parekh AB. Respiring mitochondria determine the pattern of activation and inactivation of the store-operated $\mathrm{Ca}(2+)$ current $\mathrm{I}(\mathrm{CRAC}) . E M B O$ $J$ (2000) 19:6401-7. doi:10.1093/emboj/19.23.6401

138. Gilabert JA, Bakowski D, Parekh AB. Energized mitochondria increase the dynamic range over which inositol 1,4,5-trisphosphate activates storeoperated calcium influx. EMBO J (2001) 20:2672-9. doi:10.1093/emboj/20. 11.2672

139. Hajnoczky G, Robb-Gaspers LD, Seitz MB, Thomas AP. Decoding of cytosolic calcium oscillations in the mitochondria. Cell (1995) 82:415-24. doi:10.1016/ 0092-8674(95)90430- 1

140. Gehart H, Kumpf S, Ittner A, Ricci R. MAPK signalling in cellular metabolism: stress or wellness? EMBO Rep (2010) 11:834-40. doi:10.1038/embor.2010.160

141. Marko AJ, Miller RA, Kelman A, Frauwirth KA. Induction of glucose metabolism in stimulated $\mathrm{T}$ lymphocytes is regulated by mitogen-activated protein kinase signaling. PLoS One (2010) 5:e15425. doi:10.1371/journal.pone. 0015425
142. Pollizzi KN, Powell JD. Integrating canonical and metabolic signalling programmes in the regulation of $\mathrm{T}$ cell responses. Nat Rev Immunol (2014) 14:435-46. doi:10.1038/nri3701

143. Ciesla J. Metabolic enzymes that bind RNA: yet another level of cellular regulatory network? Acta Biochim Pol (2006) 53:11-32.

144. Hentze MW, Preiss T. The REM phase of gene regulation. Trends Biochem Sci (2010) 35:423-6. doi:10.1016/j.tibs.2010.05.009

145. Hentze MW, Argos P. Homology between IRE-BP, a regulatory RNA-binding protein, aconitase, and isopropylmalate isomerase. Nucleic Acids Res (1991) 19:1739-40. doi:10.1093/nar/19.8.1739

146. Rouault TA, Stout CD, Kaptain S, Harford JB, Klausner RD. Structural relationship between an iron-regulated RNA-binding protein (IRE-BP) and aconitase: functional implications. Cell (1991) 64:881-3. doi:10.1016/0092-8674(91) 90312-M

147. Henderson BR, Menotti E, Bonnard C, Kuhn LC. Optimal sequence and structure of iron-responsive elements. Selection of RNA stem-loops with high affinity for iron regulatory factor. J Biol Chem (1994) 269:17481-9.

148. Butt J, Kim HY, Basilion JP, Cohen S, Iwai K, Philpott CC, et al. Differences in the RNA binding sites of iron regulatory proteins and potential target diversity. Proc Natl Acad Sci U S A (1996) 93:4345-9.

149. Aziz N, Munro HN. Iron regulates ferritin mRNA translation through a segment of its 5' untranslated region. Proc Natl Acad Sci U S A (1987) 84:8478-82.

150. Nagy E, Rigby WF. Glyceraldehyde-3-phosphate dehydrogenase selectively binds AU-rich RNA in the NAD(+)-binding region (Rossmann fold). J Biol Chem (1995) 270:2755-63. doi:10.1074/jbc.270.6.2755

151. McGowan K, Pekala PH. Dehydrogenase binding to the 3'-untranslated region of GLUT1 mRNA. Biochem Biophys Res Commun (1996) 221:42-5. doi:10.1006/bbrc.1996.0541

152. Pioli PA, Hamilton BJ, Connolly JE, Brewer G, Rigby WF. Lactate dehydrogenase is an AU-rich element-binding protein that directly interacts with AUF1. J Biol Chem (2002) 277:35738-45. doi:10.1074/jbc.M204002200

153. Argos P, Rossmann MG. Structural comparisons of heme binding proteins. Biochemistry (1979) 18:4951-60. doi:10.1021/bi00589a025

154. Singh R, Green MR. Sequence-specific binding of transfer RNA by glyceraldehyde-3-phosphate dehydrogenase. Science (1993) 259:365-8. doi:10. $1126 /$ science. 8420004

155. Ryazanov AG. Glyceraldehyde-3-phosphate dehydrogenase is one of the three major RNA-binding proteins of rabbit reticulocytes. FEBS Lett (1985) 192:131-4. doi:10.1016/0014-5793(85)80058-2

156. Zang WQ, Fieno AM, Grant RA, Yen TS. Identification of glyceraldehyde3-phosphate dehydrogenase as a cellular protein that binds to the hepatitis B virus posttranscriptional regulatory element. Virology (1998) 248:46-52. doi:10.1006/viro.1998.9255

157. Majewski N, Nogueira V, Bhaskar P, Coy PE, Skeen JE, Gottlob K, et al. Hexokinase-mitochondria interaction mediated by Akt is required to inhibit apoptosis in the presence or absence of Bax and Bak. Mol Cell (2004) 16:819-30. doi:10.1016/j.molcel.2004.11.014

158. Noguchi T, Inoue H, Tanaka T. The M1- and M2-type isozymes of rat pyruvate kinase are produced from the same gene by alternative RNA splicing. J Biol Chem (1986) 261:13807-12.

159. Mazurek S. Pyruvate kinase type M2: a key regulator of the metabolic budget system in tumor cells. Int J Biochem Cell Biol (2011) 43:969-80. doi:10.1016/j.biocel.2010.02.005

160. Chaneton B, Gottlieb E. Rocking cell metabolism: revised functions of the key glycolytic regulator PKM2 in cancer. Trends Biochem Sci (2012) 37:309-16. doi:10.1016/j.tibs.2012.04.003

161. Gao X, Wang H, Yang JJ, Liu X, Liu ZR. Pyruvate kinase M2 regulates gene transcription by acting as a protein kinase. Mol Cell (2012) 45:598-609. doi:10.1016/j.molcel.2012.01.001

162. Hori S, Nomura T, Sakaguchi S. Control of regulatory T cell development by the transcription factor FOXP3. Science (2003) 299:1057-61. doi:10.1126/science. 1079490

163. Williams LM, Rudensky AY. Maintenance of the FOXP3-dependent developmental program in mature regulatory $\mathrm{T}$ cells requires continued expression of FOXP3. Nat Immunol (2007) 8:277-84. doi:10.1038/ni1437

164. Regateiro FS, Chen Y, Kendal AR, Hilbrands R, Adams E, Cobbold SP, et al. FOXP3 expression is required for the induction of therapeutic tissue tolerance. J Immunol (2012) 189:3947-56. doi:10.4049/jimmunol.1200449 
165. Schmidl C, Klug M, Boeld TJ, Andreesen R, Hoffmann P, Edinger M, et al. Lineage-specific DNA methylation in T cells correlates with histone methylation and enhancer activity. Genome Res (2009) 19:1165-74. doi:10.1101/gr. 091470.109

166. Ohkura N, Hamaguchi M, Morikawa H, Sugimura K, Tanaka A, Ito Y, et al. $\mathrm{T}$ cell receptor stimulation-induced epigenetic changes and FOXP3 expression are independent and complementary events required for Treg cell development. Immunity (2012) 37:785-99. doi:10.1016/j.immuni.2012.09.010

167. Rudra D, Deroos P, Chaudhry A, Niec RE, Arvey A, Samstein RM, et al. Transcription factor FOXP3 and its protein partners form a complex regulatory network. Nat Immunol (2012) 13:1010-9. doi:10.1038/ni.2402

168. Gavin MA, Rasmussen JP, Fontenot JD, Vasta V, Manganiello VC, Beavo JA, et al. FOXP3-dependent programme of regulatory T-cell differentiation. Nature (2007) 445:771-5. doi:10.1038/nature05543

169. Floess S, Freyer J, Siewert C, Baron U, Olek S, Polansky J, et al. Epigenetic control of the FOXP3 locus in regulatory T cells. PLoS Biol (2007) 5:e38. doi:10.1371/journal.pbio.0050038

170. Kim HP, Leonard WJ. CREB/ATF-dependent T cell receptor-induced FoxP3 gene expression: a role for DNA methylation. J Exp Med (2007) 204:1543-51. doi:10.1084/jem.20070109

171. Lee KK, Workman JL. Histone acetyltransferase complexes: one size doesn't fit all. Nat Rev Mol Cell Biol (2007) 8:284-95. doi:10.1038/nrm2145

172. Houtkooper RH, Pirinen E, Auwerx J. Sirtuins as regulators of metabolism and healthspan. Nat Rev Mol Cell Biol (2012) 13:225-38. doi:10.1038/nrm3293

173. Sriram G, Martinez JA, McCabe ER, Liao JC, Dipple KM. Single-gene disorders: what role could moonlighting enzymes play? Am J Hum Genet (2005) 76:911-24. doi:10.1086/430799
174. Huberts DH, van der Klei IJ. Moonlighting proteins: an intriguing mode of multitasking. Biochim Biophys Acta (2010) 1803:520-5. doi:10.1016/j.bbamcr. 2010.01.022

175. Sirover MA. On the functional diversity of glyceraldehyde-3-phosphate dehydrogenase: biochemical mechanisms and regulatory control. Biochim Biophys Acta (2011) 1810:741-51. doi:10.1016/j.bbagen.2011.05.010

176. Tristan C, Shahani N, Sedlak TW, Sawa A. The diverse functions of GAPDH: views from different subcellular compartments. Cell Signal (2011) 23:317-23. doi:10.1016/j.cellsig.2010.08.003

Conflict of Interest Statement: The authors declare that the research was conducted in the absence of any commercial or financial relationships that could be construed as a potential conflict of interest.

Received: 01 July 2014; accepted: 13 August 2014; published online: 28 August 2014. Citation: Howie D, Waldmann H and Cobbold S (2014) Nutrient sensing via mTOR in $T$ cells maintains a tolerogenic microenvironment. Front. Immunol. 5:409. doi: 10.3389/fimmu.2014.00409

This article was submitted to Inflammation, a section of the journal Frontiers in Immunology.

Copyright (c) 2014 Howie, Waldmann and Cobbold. This is an open-access article distributed under the terms of the Creative Commons Attribution License (CC BY). The use, distribution or reproduction in other forums is permitted, provided the original author(s) orlicensor are credited and that the original publication in this journal is cited, in accordance with accepted academic practice. No use, distribution or reproduction is permitted which does not comply with these terms. 